\title{
Palaeoceanographic and palaeoclimatic changes during the last 37,000 years detected in the SE Bay of Biscay based on benthic foraminifera
}

\author{
Pascual A. ${ }^{1,{ }^{*}}$, Rodríguez-Lázaro J. ${ }^{1}$, Martínez-García B. ${ }^{1,2}$, Varela Z. ${ }^{1}$
}

${ }^{1}$ Dpto. Estratigrafía y Paleontología. Fac, Ciencia y Tecnología, Universidad del País Vasco UPV/EHU, Barrio Sarriena s/n, 48940, Leioa, Bizkaia, Spain

2 Sociedad de Ciencias Aranzadi, Centro Geo-Q, Mendibile kalea, 48940, Leioa, Spain

* Corresponding author : A. Pascual, email address : ana.pascual@ehu.eus

julio.rodriguez@ehu.eus ; blancamaria.martinez@ehu.eus ; zeltia.varela@ehu.eus

\begin{abstract}
:
Benthic foraminifera assemblages from a sedimentary core (PP10-12; $701 \mathrm{mwd}$ ) from the SE Bay of Biscay allow us to trace palaeoceanographic and palaeoclimatic changes occurred in this region during mid MIS 3 (Marine Isotope Stage 3) and MIS 1 interval (37-2.4 ka BP). Results are based on 176 benthic foraminifera species considering their ecology, the difference between autochthonous/allochthonous, preservation and oxygen rates, thus evidencing climatic and oceanographic events. MIS 3 is characterised by waters with a dominance of Cassidulina laevigata and Uvigerina peregrina. By the end of this interval, waters became colder and less oxygenated indicated by the occurrence of Melonis affinis. These conditions persisted at the beginning of MIS 2. The Heinrich Event $1(\mathrm{H} 1)$ is well registered in this core with three intervals (H1a, H1s.s., H1b) where Hyalinea balthica dominates. During H1s.s. the coldest waters are registered, and the environment was unstable. These conditions continued during $\mathrm{H} 1 \mathrm{~b}$ when the occurrence of Globobulimina affinis evidences some intervals with anoxia. During Bølling-Allerød $(\mathrm{B} / \mathrm{A})$ waters were warmer and low-ventilated indicated by Bulimina gibba. Cassidulina laevigata dominates the Younger Dryas (YD) and the beginning of Lower Holocene, evidencing the occurrence of cool waters with low-oxygen and high organic matter content. The Lower to Middle Holocene transition is registered as a cold interval: Holocene Cooling Event (HCE-5). From the Middle Holocene onward water temperature were milder based on the dominance of Uvigerina peregrina.
\end{abstract}

Keywords : Palaeoclimatology, Palaeoceanography, Benthic foraminifera, MIS 3-MIS 1, Bay of Biscay 


\section{Introduction}

Earth's climate is conditioned by the interaction between the atmosphere and the ocean by heat and $\mathrm{CO}_{2}$ mutual exchange. The Atlantic Ocean is the main location of new water masses that travel as a conveyor belt distributing the caloric energy from low to higher latitudes in the planet. In this context it is fundamental to know the dynamic of the AMOC (Atlantic Meridional Overturning Circulation) if we try to characterise millennial climate changes of cold to warm alternating periods of climate of the Quaternary (Rahmstorf et al., 2015).

The AMOC is formed by two interconnected gyres in the North Atlantic: The Subtropical Gyre (STG) and the Subpolar Gyre (SPG). The STG travels to the north transferring heat and salinity to the Nordic seas (Morley et al., 2014) and there is a convection there (Lozier and Stewart, 2008). The SPG flows transporting cold waters to the south. The dynamics between these two gyres caused climatic anomalies in Europe as the Little Ice Age (LIA) and the Warm Medieval Period and other secular anomalies (Thornalley et al., 2009; Morley et al., 2014; Reißig et al., 2019) thus evidencing an atmospheric/oceanic interconnection.

Micropalaeontological data are one of the most used proxies in palaeoceanography and foraminifera are the most popular among them. These faunal analyses are based on the high sensitivity of many foraminifera species to basic environmental parameters of the marine realm (Murray, 2006). The current knowledge of the biology and ecology of living foraminifera species is a useful database to decipher those environmental parameters of the past (Murray, 1991). Thus, the distribution of modern foraminifera species in the Bay of Biscay has been described in the northern margin of the Capbreton Canyon in Aquitaine platform (Caralp et al., 1970; Pujos-Lamy, 1973, Fontanier et al., 2002, 2003; Langezaal et al., 2006; Duchemin et al., 2008; Ernst et al., 2008; Mojtahid et al., 2010) and in the Basque Basin southern canyon region (Pascual et al., 2008; Martínez-García et al., 2013). These works, located from shelf to bathyal profiles, described benthic foraminifera assemblages controlled by parameters as organic carbon flux to the marine benthos, bottom currents and grain size, oxygen content and carbonate saturation of sediments (Mackensen et al., 1995; Jorissen et al., 2007). The distribution of living benthic foraminifera assemblages have been used as proxies of the response of benthic ecosystems to atmospheric changes and rapid climatic changes in the North Atlantic (Baas, 1998; Rasmussen et al., 2002; García et 
al., 2013; Grunert et al., 2015) among others. In the Bay of Biscay Martínez-García et al. (2014) described climatic events from the MIS 3 to the Holocene registered in the Basque shelf, however from $\mathrm{H} 1$ to Holocene were scarcely recorded due to various sedimentary hiatuses. Rodríguez-Lázaro et al. (2017) studied the palaeoclimatic evolution of the bathypelagic zone of this region during the last $140 \mathrm{ka}$, that is, MIS 5 to MIS 1 interval, with a low resolution for the MIS 1.

The aim of this work is to provide with new evidence of the response of benthic foraminifera assemblages to rapid climatic changes occurring during modern times of the last glacial cycle in a mesopelagic palaeoceanographic context of the SE Bay of Biscay, with detailed study of $\mathrm{H} 1$ to Recent, a poorly known interval.

\section{Environmental setting}

The study area is located in SE Bay of Biscay (Fig. 1A) north of Cap-Breton Canyon: $701 \mathrm{mwd}$, Lat (WGS84) 43.836256; Lon (WGS84) -2.123051. Considering the modern water masses in the Bay of Biscay the study area is located in the boundary between the MOW (Mediterranean Outflow Water) with a bathymetry of $1300-700 \mathrm{~m}$ and the ENACW (East North Atlantic Central Water) shallower than $700 \mathrm{~m}$ (Fig. 1B). In the hydrographic context of the Bay of Biscay the study area belongs to the east border of the NAC (North Atlantic Current) not far from divergence area of STG (subtropical gyre) and SPG (subpolar gyre) (Mary et al., 2017) (Fig. 1A). This particular geographic location favoured the record of climatic changes in the N Atlantic (i.e. García-Soto and Pingree, 2012; Esnaola et al., 2013).

The main surface current in the Bay of Biscay is the European Slope Current (ESC) that flows northwards to the Armorican Shelf (Fig. 1A). This current can revert through the talus and the north Spanish shelf to the southwest during the summer following the talus border (Charria et al., 2013). During fall-winter this current flows northwards converging with the Iberian Poleward Current (IPC) coming from the south along the western Iberian margin (Peliz et al., 2005) (Fig. 1A). The IPC entering the Bay of Biscay is called Navidad current (García-Soto et al., 2002). The winter combination of IPC and ESC forms the European Poleward Current (EPC) (García-Soto and Pingree, 2012) that transports relatively warm and salty water to the Nordic seas. The surface waters from the NAC entering the Bay of Biscay from the northwest (Pingree and García-Soto, 2014) are under the influence of interannual westerlies (Pingree, 2005) associated with the North Atlantic Oscillation (NAO) considered as one of the clues to understand the climatic variability of the $\mathrm{N}$ Atlantic. 
The palaeoceanographic evolution of the Iberian Margin during the last climatic cycle is considered by Martrat et al. (2007), that evidenced the Antarctic Bottom Water (AABW) input during glacial periods and the colder short-lived intervals of interglacials. During deglacials the early entrance of North Atlantic Deep Water (NADW) from high latitudes is observed, particularly during warmer and free of sea ice interglacials. In the Holocene deep water were more ventilated due to the influence of NADW. During the interval of $20 \mathrm{ka}-10 \mathrm{ka}$, after the deglaciation inception, climatic conditions evolved to low oxygen environments and a decrease of current intensity. This trend is abruptly changed by strong fall of sea-surface T (SST) together with strengthening of bottom currents caused by the entrance of deep waters originated in the south (AABW) (Martrat et al., 2007). After a rapid cooling produced in only several centuries, the absence of ventilation of bottom waters and the lower input of AABW forced the instauration of warmer conditions with SST increase. This trend is repeated during the SST oscillations observed in the last glacial-interglacial climatic cycle.

\section{Material and methods}

Samples of this study belongs to sedimentary core PP10-12, $18 \mathrm{~m}$ long, retrieved south of Landas shelf, $701 \mathrm{mwd}$, during the oceanographic cruise SARGASS, 2010. The core is composed by homogenous lithology of continuous silt-clay sediment. The bottom core is formed by laminated silty facies indicative of more energetic environment. From level $1561 \mathrm{~cm}$ to the top the sediment is homogeneous clay-silt. There is no evidence of reworking. Core was sampled every $\mathrm{cm}$ and 121 of these samples were used to micropalaeontologic analyses in this work. As the main aim of work is detailed study of $\mathrm{H} 1$ to MIS 1 this interval has been sampled with more detail (1 sample $/ 20 \mathrm{~cm}$ ) and supplementary intermediate samples were studied to complete the results. As core dating are provided we sampled the bottom half with lower resolution in order to describe the main palaeoenvironments previous to $\mathrm{H} 1$. Samples have been washed and sieved and fraction coarser than $63 \mu \mathrm{m}$ have been picked from micropalaeontology following the standard method (Boltovskoy and Wright, 1976; Murray, 2006). A total of 300 specimens of benthic foraminifera have been picked for every sample and the associated planktonic foraminifera have also been included. Taxonomy for the benthic foraminifera study is based on Loeblich and Tappan (1988) and Holbourn et al. (2013) among others, and updated with WoRMS databases (last reference 30-11-2019). 
In order to stablish the taphonomic imprint as transport and/or dissolution, the degree of preservation of benthic foraminifera carapaces have been studied. Carapaces are well preserved in general, with few fractures or reworking signals and thus with no evidence of transport nor re-sedimentation. Most important alterations in carapaces are the translucid aspect and red/brown colour only found in few levels of this core. The colour change indicates permineralization occurring in early diagenesis by interstitial fluids affecting the organic matter included in carapaces, in sediment with reducing conditions (Murray, 2006).

The assemblages have been quantified by simple diversity index (S, number of species by sample). Other calculated indices of richness and diversity (as Fisher's $\alpha$ index) do not show significant oscillations in the studied core. The simple Oceanity Index of Murray (1976) (OI; number of planktonic/total foraminifera) that considers the total foraminifera of each sample has been used. For this calculation we have not excluded individuals of infaunal species as suggest Van der Zwaan et al. (1990) nor individuals of stress indicator species as indicate Van Hinsbergen et al. (2005). For that reason, this index is a good indicator of the stress in the bottom waters (Van Hinsbergen et al., 2005). When the bottom waters represent an altered ecosystem, benthic species are virtually absent from the sediment and OI increases drastically as a consequence of the increase of planktonic foraminifera deposited in the bottom. Conversely, when the ecosystem recovers stability, by increasing the oxygen level for example, the lower OI values are reached.

Benthic foraminifera species indicative of oxygen levels have been studied following the classification of Kaiho $(1994,1999)$ (Appendix 1). In order to evaluate the degree of transportation, to evidence strong supplies from coastal areas to deeper waters in this region, the percentage of benthic allochthonous species transported from the shelf has been calculated (Appendix 2). In this group we found specimens living in estuaries (Cearreta, 1988, 1989, Pascual and Rodríguez-Lázaro, 2006, Pascual et al., 2019), as well as in shelf and coastal sediments of the Bay of Biscay (Pujos-Lamy, 1973; Pascual et al., 2008; Martínez-García et al., 2013).

Chronology of the studied core has been stablished from $11 \mathrm{AMS}^{14} \mathrm{C}$ dates from planktonic foraminifera (Beta Analytic Inc., Florida, USA) calibrated with 'CalibRev6.0.6' software (Stuiver and Reimer, 1993; Stuiver et al., 2005) using the Marine09.14C calibration (Reimer et al., 2009). These dates have been complemented with the correlation of percentages of planktonic foraminifera Neogloboquadrina pachyderma $\sin \left(\mathrm{Np}_{\mathrm{sin}}\right)$, with $\delta^{18} \mathrm{O}$ signature of marine core MD95-2042 (Shackleton, 
2001) and Greenland ice core NGRIP GICC05 (Rasmussen et al., 2014; Seierstad et al., 2014), obtaining 40 additional tie-points (Table 1, Fig. 2). The best model correlation has been obtained with a non-linear logistic analysis calculated with PAST software (Hammer et al., 2001).

\section{Results}

\subsection{Chronostratigraphy of core $P P 10-12$}

The age model of core PP10-12 allows us grouping samples into stratigraphical units belonging to MIS 3 to MIS 1, with ages into the 36710-2430 years BP interval (Fig. 3). The high sedimentation rate of this core (from $5.1 \mathrm{~cm} / \mathrm{ka}$ at the beginning of the MIS 2 to $750 \mathrm{~cm} / \mathrm{ka}$ at the beginning of the MIS 1 ; mean $=142.25 \mathrm{~cm} / \mathrm{ka}$ ) allows a highresolution study particularly of MIS 2 and MIS 1 . In this way, we found the three substadials of Heinrich event $1(\mathrm{H} 1$ : H1a, H1s.s., $\mathrm{H} 1 \mathrm{~b})$ already described in other locations of this region (Martínez-García et al., 2014, 2015).

The high-resolution time obtained in the H1-Lower Holocene interval allow us to identify 29 tie-points between $\delta^{18} \mathrm{O} \mathrm{Np}_{\text {sin }}$ and reference cores, supported by $\mathrm{AMS}^{14} \mathrm{C}$ dates obtained for this interval (Table 1; Figs. 2 and 3). In the rest of core 11 further interpretative tie-points have been obtained with lower resolution, so it does not permit such a detailed palaeoenvironmental interpretation.

\subsection{Microfaunal analyses}

A total of 35630 specimens of benthic foraminifera (BF) grouped in 176 species have been identified in this study (Table 2). Only 12 species count more than $10 \%$ in more than two samples (supplementary material). Other 5 species count more than $10 \%$ of total in at least one sample, 13 more are $<10 \%$ to $5 \%$ in at least one sample.

Remaining species (136) are minoritarity species, 77 of them counting $<1 \%$ only present in some samples. 31 species are only represented by one individual and 16 more by two specimens. The most abundant ( $>10 \%$ of the total BF, see supplementary material) are: Cassidulina laevigata d'Orbigny and Uvigerina peregrina Cushman. Bulimina gibba Fornasini and Hyalinea balthica (Schröter) are secondary species (5$10 \%)$. Other less abundant (1-5\%) species are: Bigenerina (Bigenerina) nodosaria d'Orbigny, Bolivina spathulata (Williamson), Bolivina subaenariensis Cushman, Chilostomella oolina Schwager, Cibicidoides pachyderma (Rzehak), Globobulimina affinis (d'Orbigny), Melonis affinis (Reuss) and Nonionoides turgidus (Williamson). 
Specimens exhibit in general tests with good preservation except those of $H$. balthica and B. subaenariensis found during the Last Glacial Maximum (LGM) and Heinrich H1s.s. intervals.

Benthic foraminifera assemblages present high values of simple $S$ diversity (average: $S=39 \mathrm{spp} /$ sample) and diversity is lower during MIS $3(\mathrm{~S}=21)$ (Fig. 4). Diversity is also below average during the beginning of MIS 2, $\mathrm{H} 1 \mathrm{a}$ and Middle (Northgrippian) and Upper (Meghalayan) Holocene. Highest values are found during $\mathrm{H} 1 \mathrm{~b}$, Bølling/Allerød (B/A), Younger Dryas (YD) and Lower Holocene (Greenlandian). Noteworthy, all of these episodes begin and end with a drastic fall of diversity $(S<30)$ (Fig. 4).

Considering the oxygenic character of the studied benthic foraminifera it is evident the dominance of suboxic (O2: 0.3-1.5 ml/l) assemblages with an average of $60 \%$ (Fig. 5 and supplementary material). Oxic (O2 $>1.5 \mathrm{ml} / \mathrm{l})$ species are important in percentage only during H1s.s. and H1b. Species that can live in dysoxic (O2: 0.1-0.3 ml/l) waters dominate the record of MIS 2, the B/A (<45\%) and the end of Greenlandian (Lower Holocene, see Fig. 5).

The planktonic/benthic signal of Oceanity Index (OI) averages 59\% throughout the studied core (Fig. 4). This index is lower during MIS 3 (H3: 32\%), end of LGM, B/A, YD and beginning of Holocene. OI increases during the rest of Holocene. The Ol shows a rapid oscillation (OI: 80\%-25\%) during $\mathrm{H} 1$, and especially during $\mathrm{H} 1$ s.s. (see Fig. 4). These levels of Heinrich event $\mathrm{H} 1$ also evidence the strongest variations of the occurrence of BF coastal species, that increases from the average of $9 \%$ to values of $25 \%$ reaching the $45 \%$ in some levels of H1s.s. (see Fig. 4).

Considering dominant species MIS 3 (levels $1797-1670 \mathrm{~cm}$ ) is characterized by the assemblage of $C$. laevigata and $U$. peregrina, accompanied by $H$. balthica. Also, in some levels $B$. subaenariensis, C. pachyderma and M. affinis are present (Fig. 6).

From the beginning of MIS 2 to the end of LGM (27-19 ka cal BP) C. laevigata is abundant, accompanied by $B$. subaenariensis and $H$. balthica. These two species contain abundant individuals with brown-colour altered tests that count for more than $40 \%$ of the total specimens at the beginning of MIS 2 (Fig. 4). During $\mathrm{H} 1$ (a, s.S., b) episodes (19-14.8 ka cal BP) main species $C$. laevigata and $H$. balthica occur anticovariantly. Cassidulina laevigata reaches $30 \%$ in $\mathrm{H} 1$ a while $\mathrm{H}$. balthica counts for more than $50 \%$ in levels of H1s.s. (Fig. 6). H. balthica also includes specimens altered with brown colour. Other secondary species are $U$. peregrina $(\mathrm{H} 1 \mathrm{a}), B$. spathulata and M. affinis (H1ss), C. oolina, G. affinis and N. turgidus (H1b) (Fig. 6). 
MIS 1 is represented in this core from sample $921 \mathrm{~cm}$ to coretop. In levels of B/A (14.8$12.8 \mathrm{ka}$ cal BP) B. gibba is the most abundant species (>25\% in some levels) together with $U$. peregrina (17\%) both species with oscillating records. Maxima percentages of $U$. peregrina (>40\%) are found in earliest and latest levels of $B / A$. In some levels these species are accompanied by abundant individuals of $M$. affinis and $C$. oolina (see Fig. $6)$.

During YD (12.8-11.7 ka cal BP) C. laevigata is again dominant together with M. affinis, though this unit begins and ends with high occurrence of $U$. peregrina (Fig. 6). The Lower Holocene (Greenlandian, 11.7-8.2 ka cal BP) shows comparable assemblages together with $B$. gibba, while $B$. spathulata is important numerically at the beginning of this unit. The Lower to Middle Holocene transition (HCE 5, $8.2 \mathrm{ka}$ cal BP) is marked by the net occurrence of $G$. affinis and H. balthica (>20\%) (Fig. 6). The Middle Holocene (Northgrippian, 8.2-4.3 ka cal BP) is characterised by the increase of percentage of $U$. peregrina (average: $46 \%$; up to $70 \%$ in some levels), together with $G$. affinis at the beginning and $B$. (B.) nodosaria at the end of this unit (Fig. 6). Finally, during the Upper Holocene (Meghalayan, 4.3-2.4 ka cal BP in this core) $U$. peregrina is dominant species and reaches the highest percentage in all core $(<72 \%)$, being accompanied by B. (B.) nodosaria and C. pachyderma to the top of this unit (Fig. 6).

\section{Discussion}

Benthic foraminifera contained in studied core PP10-12 is indicative of benthic particular conditions as oxygenation, organic matter (OM) and productivity of waters (Table 3). The ecology of benthic foraminifera species occurring in this core (Table 1) evidence particular benthic conditions relative to water temperature, oxygenation, organic matter and productivity.

\subsection{End of MIS 3 - beginning of MIS 2}

During the time of MIS 3 included in this work (36-27 ka cal BP) SE Bay of Biscay bottom waters were cool to temperate as evidenced by the occurrence of shallowinfaunal benthic species C. laevigata (Rasmussen et al., 2002). Nevertheless cold and high content organic matter waters arrived seasonally as indicated by the occurrence of $C$. laevigata and $H$. balthica, an intermediate infaunal species that dominated during 
MIS 3 in the Mediterranean (Ross, 1984). These waters were less oxygenated as it contained $B$. subaenariensis, indicative of dysoxia $\left(\mathrm{O}_{2}:\right.$ 0.1-0.3 ml/I) (Kaiho, 1994).

These organic matter fluxes were intermittent which is supported by the occurrence in some levels of shallow infaunal benthic species as C. pachyderma (see Fig. 6), typical of oligotrophic, high-oxygen content and low nutrients waters (Schmiedl et al., 2000; Table 3). At the end of MIS 3 some instability of benthos is detected by the drastic decreasing of diversity (S from 48 to 21 species) and the OI (see Fig. 4). Melonis affinis increased as well, a species indicative of very cold waters (from $-0.4^{\circ} \mathrm{C}$ to $9^{\circ} \mathrm{C}$ ) (Murray, $1991)$; all of this would indicate the arrival of relatively colder waters.

At the beginning of MIS 2 the cold, low oxygen and high OM water conditions persisted. Waters were very cold and became progressively dysoxic as evidenced by the occurrence of abundant specimens of $B$. subaenariensis in the lower levels of MIS 2 (Fig. 6). This species includes many individuals with altered, dark brown or red coloured tests (see Fig. 4), indicative of low oxygen and high OM content waters (reducing conditions). Similar alteration has been observed in tests of $H$. balthica from deep canyons of Mediterranean (Fontanier et al., 2008) and Atlantic (Hess and Jorissen, 2009). This has been interpreted as produced after early colonisation of altered ecosystems, in some cases after the deposition of turbidites. Comparable alteration has been described with the same species in the Aegean Sea after the low oxygen sapropel event S1 (Abu-Zied et al., 2008) as well as in the Ionian Sea (Rosenthal et al., 2011) after the anoxic phase that triggered the deposit of sapropel S5.

\subsection{Heinrich Event $H 1$}

In the stadial $\mathrm{H} 1$ the benthic foraminifera allow recognising three intervals ( $\mathrm{H} 1 \mathrm{a}, \mathrm{H} 1$ s.s., $\mathrm{H} 1 \mathrm{~b})$ already described in shelf sediments of the Bay of Biscay (Martínez-García et al., $2014,2015)$ that are characteristics of the last deglaciation in NW Iberian margin (Naughton et al., 2016). These intervals have been attributed to changes in the direction of jet stream which was produced by mechanisms similar to the modern North Atlantic Oscillation (NAO) (Naughton et al., 2009).

During $\mathrm{H} 1 \mathrm{a}$ (19-17.4 ka cal BP) C. laevigata dominated, though the increase of $H$. balthica is indicative of progressively colder waters (Fig. 6). This interval was interpreted as a cold and relatively wet interval (Naughton et al., 2016). Penaud et al. (2009) described the most important supply of fluviatile terrigenous sediments of the 
Celtic-Armorican margin at around $18 \mathrm{ka}$., considered as a response to the seasonal water supplied by the retreat of European ice sheets (Toucanne et al., 2009).

During H1s.s. (17.4-16.2 ka cal BP) the high occurrence (<50\%; Fig. 6) of H. balthica, supported by M. affinis, indicate cold waters for this interval (see Table 3). Suboxic species were living in these waters though the occurrence of some oxic $\left(\mathrm{O}_{2}>1.5 \mathrm{ml} / \mathrm{l}\right)$ species as $C$. pachyderma in the sediment $(<67 \%)$ would indicate levels with better oxygenation (Table 3 ) and thus an environmental amelioration. On the other side, altered brown colour tests of $H$. balthica are found (see Fig. 4). In these levels, $C$. laevigata and $H$. balthica exhibit anti-covariant record. All these data are indicative of an unstable period of the benthos, what is supported by the oscillation of the number of species (22-48) as well as the OI (IO: 24-87; see Fig. 4) and also by the entrance of coastal species $(<46 \%)$ indicative of increasing riverine activity. Episodes with highest values of the Oceanity Index are indicative of an altered ecosystem in a marine bottom depleted of oxygen with scarce life (Van Hinsbergen et al., 2005). In this deteriorated environment we found many benthic coastal foraminifera that have been transported by energetic currents to this bottom. This environmental change is also produced by the episodic arrival of warmer waters evidenced by the high occurrence (highest values of core) of $B$. spathulata, species which prefer temperatures between $17^{\circ}-25^{\circ} \mathrm{C}$ (Table 3) (Murray, 2006).

These abrupt climate changes might be related to episodes with thermohaline current reduction (Obbink et al., 2010). Effectively during H1s.s. polar conditions prevailed in NE Europe, with massive iceberg discharges of the ice sheet (Zaragosi et al., 2001), that caused the AMOC shutdown at $17.5 \mathrm{ka}$ cal BP in the N Atlantic (McManus et al., 2004). The ice discharges had triggered drastic conditions in surface waters with seasonal sea ice development around continental borders of the Bay of Biscay (Penaud et al., 2009). Based upon this the benthic foraminifera occurring in some levels of this interval H1s.s. indicate the coldest episodes registered in the whole core.

The instability continues during $\mathrm{H} 1 \mathrm{~b}$ (16.2-14.8 ka cal BP). Cold waters are evidenced by $H$. balthica and low oxygen indicated by Globobulimina affinis, C. oolina and $N$. turgidus (Fig. 6). These species are opportunistic, deep infaunal associated with high nutrient and low oxygen content (Table 3) (Bernhard and Sen Gupta, 1999). The oxygen depletion is likely influenced by the AMOC slowdown caused by the massive fresh water discharge from deglaciation by the end of LGM. Globobulimina affinis is indicative of dysoxia or even anoxia (Fontanier et al., 2002) and has been previously 
associated to massive iceberg discharges during Heinrich events of MIS 4-MIS 2 interval in deeper waters (>2100 m) of the Bay of Biscay (Loncaric et al., 1998; Rodríguez-Lázaro et al., 2017) and also in the Basque shelf during H1 (MartínezGarcía et al., 2014, 2015). To the top of H1b G. affinis, a bathyal species, is replaced by C. oolina coincident with high percentage of coastal species (29\%; see Fig. 4). Chilostomella oolina is typical of dysoxic-anoxic sediments with high OM (Table 3 ) and replaces G. affinis when the quality of OM increases (Fontanier et al., 2002). Thus, shifts of $C$. oolina indicate the amelioration of surface water conditions. This change can be also related to the arrival of surface waters warmer than those from the beginning of $\mathrm{H} 1 \mathrm{a}$ and produced by northern displacement of the polar front (Naughton et al., 2009). The same change had been detected in other sites of the Bay of Biscay (Martínez-García et al., 2014, 2015). The end of MIS 2 is marked by un important decrease of the Oceanity Index and diversity $(\mathrm{OI}=33 ; \mathrm{S}=31)$ (Fig. 4).

From these results we conclude that during MIS 2 benthos in this area was characterised by very cold waters with highly trophic levels and a variable oxygenation. In this interval, $\mathrm{H} 1$ is characterised in general by enrichment of organic matter in a low oxygenated benthos. During Heinrich events a big amount of continental ice arrived to the $\mathrm{N}$ Atlantic and affected the thermohaline production by reduction of salinity and thus, density of surface waters. The reduction of deep-water formation produced the accumulation of OM in the hypoxic marine bottom (Loncaric et al., 1998). The results based on benthic foraminifera from core PP10-12 support those by Grunert et al. (2015) of the temporal slowdown or even total shutdown of the AMOC during $\mathrm{H} 1$ event.

\subsection{Bølling-Allerød and Younger Dryas}

At the beginning of MIS 1 the Oceanity Index is yet below core average $(\mathrm{OI}<60)$ (Fig. 4) and suboxic specimens dominated (Fig. 5). Nevertheless, during Bølling-Allerød (B/A: 14.8-12.8 ka cal BP), the number of species increased while the occurrence of coastal species drastically decreased (<12\%) (Fig. 4). The increase of disoxic species (> 50\%) (Fig. 5) evidences a very low oxygen waters where $B$. gibba dominated. This is a cold to temperate $\left(5^{\circ}-17^{\circ} \mathrm{C}\right)$, extremely euthophic and anoxic species (Table 3 ) indicative of low ventilated benthic environments (Fontanier et al., 2002). B. gibba is accompanied by $U$. peregrina mostly at the beginning and end of B/A interval (Fig. 6). The relative warming during these two moments could be due to the gradual increase of precipitation and the growing influence of westerlies produced by the reactivation of the AMOC intensity. The warming of B/A had been previously cited in other areas of the Bay of Biscay (Zaragosi et al., 2001; Toucanne et al., 2008; Penaud et al., 2009; 
Martínez-García et al., 2014, 2015). In this temperate and extremely dysoxic environment it is registered the entrance of colder waters in particular intervals as Greenland Interstadials Gl1d (14.0-13.9 ka cal BP), Gl1c2 (13.5 ka cal BP) and Gl1b (13.2-13.1 ka cal BP) (Fig. 2). These intervals are identified here by the occurrence of B. gibba, B. subaenariensis, C. laevigata and C. oolina (Fig. 6). This cooling might correspond to $\mathrm{AMOC}$ oscillations due to freshwater discharges and/or insolation or atmospheric variations related to $\mathrm{CO}_{2}$ cycle (Liu et al., 2009; Obase and Abe-Ouchi, 2019).

As occurred in the B/A, the Younger Dryas (YD; 12.8-11.7 ka cal BP) started and ended with a strong fall of diversity (YD, $S<30$; see Fig. 4) as well as with an increase of $U$. peregrina (Fig. 6). The high occurrence of $C$. laevigata during the YD is indicative of the arrival of waters with high OM content (Rasmussen et al., 2002) and M. affinis indicates cold waters. These results point to a new cooling, not as strong as $\mathrm{H} 1$, probably generated by slowdown of $\mathrm{AMOC}$ and southern shift of the polar front (Naughton et al., 2016). The YD cooling has been previously described in the Bay of Biscay by Zaragosi et al. (2001) and Toucanne et al. (2008). These waters progressively warmed during the YD/Lower Holocene-Greenlandian transition since abundant specimens of warm-water foraminifera species, $B$. spathulata, occur at these levels (Fig. 6).

\subsection{Holocene}

Benthic foraminifera have been used to detect environmental changes in the Holocene, thus Mary et al. (2017), described thermal anomalies in surface waters of the last $10 \mathrm{ka}$ in the Bay of Biscay. Positive (warming) boreal climate would be associated to positive SST during episodes of more intense North Atlantic Current (NAC) in the Subpolar Gyre (SPG). Opposite negative cold anomaly would occur with weaker SPG (Mary et al., 2017).

The beginning of Lower Holocene (Greenlandian; 11.7-8.2 ka cal BP) is characterised by the occurrence of $B$. spathulata indicating warm waters (Table 3 ). Also appear $U$. peregrina, considered a species typical of the Holocene (Rodríguez-Lázaro et al., 2017) and living in cool to temperate, oxygenated, seasonal flux of high productivity OM waters (Table 3; García et al., 2013). The abundant specimens of $C$. laevigata in some levels indicate the entrance of cool, low oxygen and high OM waters related to upwelling or seasonal flux (Pascual et al., 2008). The Ol increases in this stage and reach the maximum value of the core $(\mathrm{OI}=94)$. In this interval of environmental recuperation this elevated OI could be caused by Melt Water Pulse (MWP) 1B 
occurred at the YD/Lower Holocene transition (Bard et al., 2010; Carlson and Clark, 2012). The Lower-Middle Holocene (Greenlandian/Nordgrippian) boundary is represented by very cold and dysoxic waters (H. balthica and G. affinis) (Fig. 6), likely indicative of the Holocene Cooling Event 5 (HCE 5) when climate became colder and dryer due to AMOC slowdown (Alley and Ágústsdóttir, 2005) (8.2 Ka BP; sample 251 $\mathrm{cm}$ of core) (see Fig. 2). The occurrence of $B$. (B.) nodosaria (typical T, 15을 Mathieu, 1986) from the end of Middle Holocene to the end of core points to a warming of the water, with a stable environment (U. peregrina) that continued during the Upper Holocene (Megalayan: 4.3-2.4 ka cal BP). To the top of this core (2823-2430 years cal BP) a high concentration of oxygen in waters is detected by abundant individuals of $C$. pachyderma.

\section{Conclusions}

Benthic foraminifera assemblages allow us to register palaeoceanographic and palaeoclimatic changes in the SE Bay of Biscay during last 37 ka (MIS 3-MIS 1). Quantification of the ecology of main species, diversity, Oceanity Index (OI), percentages of coastal allochthonous and oxygen and organic matter content species permit characterizing environmental parameters as thermal character, oxygenation and productivity and to relate them to climate modifications. On the other side, taxonomic identification of 176 benthic foraminifera species is a contribution to the knowledge of the Quaternary palaeodiversity of the Bay of Biscay.

MIS 3 is characterized by benthic cool waters dominated by the species $C$. laevigata and $U$. peregrina. The entrance of colder waters by the end of MIS 3 is detected by decreasing of diversity (number of species, S) and OI, as well as by the occurrence of M. affinis, a typical cold and low-oxygen species. These conditions persisted at the beginning of MIS 2 .

In the stadial $\mathrm{H} 1$ benthic foraminifera allow us to consider three phases $(\mathrm{H} 1 \mathrm{a}, \mathrm{H} 1 \mathrm{s.s}$, $\mathrm{H} 1 \mathrm{~b})$. This event is the coldest registered in this work. During H1s.s. waters were extremely cold and the environment was unstable with oscillations of oxygenation of the bottom. During $\mathrm{H} 1 \mathrm{~b}$ the occurrence of $G$. affinis indicates anoxia in the benthos. To the end of $\mathrm{H} 1 \mathrm{~b}$ foraminifera indicate the arrival of warmer waters.

The beginning of Bølling-Allerød $(B / A)$ is characterized by the occurrence of suboxic species and the absence of coastal individuals. During the Bølling-Allerød (B/A) $B$. gibba dominated, indicative of warmer and low ventilated waters. Nevertheless, during 
B/A punctual influence of colder waters is detected in Greenland Interstadials (GI1d, Glc2 y Gl1b).

Cassidulina laevigata is dominant during the Younger Dryas indicating cool, low oxygenated and high organic matter waters.

Lower Holocene waters in the Bay of Biscay tempered as evidenced by species $U$. peregrina and $B$. spathulata. To this milder environment intermittently arrived colder, low-oxygen and high organic matter waters produced by upwelling processes. In the Lower-Middle Holocene boundary waters became colder and dysoxic as evidenced by $H$. balthica and $G$. affinis, characterising the Holocene Cooling Event 5. The Middle and Upper Holocene waters were warmer than previous times (U. peregrina, B. (B.) nodosaria) and waters were more oxygenated in recent times as indicated by $C$. pachyderma.

\section{Acknowledgements}

This work has been supported by HAREA-Coastal Geology Research Group (EJ/GV, IT 976-16) and by the Spanish Ministerio de Economía y Competitividad MINECO (CHIMERA project, ref. CTM2016-75411-R). M. Cremer, EPOC, UMR 5805, Bordeaux I University is thanked for all facilities with samples of core PP10-12.

Appendix 1. Benthic foraminifera assemblages indicative of oxygen content (Kahio, 1994, 1999).

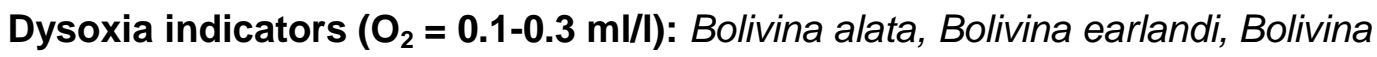
italica, Bolivina pseudoplicata, Bolivina pygmaea, Bolivina spathulata, Bolivina subaenariensis, Bulimina gibba, Bulimina marginata, Bulimina striata, Chilostomella oolina, Chilostomella ovoidea, Eubuliminella exilis, Fursenkoina complanata, Fursenkoina bradyi, Globobulimina affinis, Globobulimina auriculata, Globobulimina pyrula, Globobulimina sp. cf. ovula.

Suboxia indicators $\left(\mathrm{O}_{2}=\mathbf{0}\right.$-3-1.5 $\left.\mathrm{ml} / \mathrm{l}\right)$ : Bolivinita quadrilatera, Cassidulina laevigata, Seguenzaella lacunata, Evolvocassidulina bradyi, Favulina squamosa, Fissurina cucullata, Fissurina lucida, Fissurina marginata, Fissurina orbignyana, Grigelis guttiferus, Gyroidina umbonata, Hansenisca soldanii, Hoeglundina elegans, Homalohedra acuticosta, Hyalinonetrion gracillima, Laevidentalina advena, 
Laevidentalina elegans, Laevidentalina filiformis, Laevidentalina inornata,

Laevidentalina subsoluta, Lagena elongata, Lagena hispidula, Lagena semistriata, Lagena striata, Lagena substriata, Lagena sulcata, Lenticulina calcar, Lenticulina gibba, Lenticulina iota, Lenticulina orbicularis, Melonis affinis, Melonis pompilioides, Neolenticulina peregrina, Neouvigerina proboscidea, Nonion boueanum, Nonion commune, Nonionellina labradorica, Nonionella sp. cf. bradii, Nonionoides turgidus, Oolina globosa, Parafissurina malcolmsonii, Pseudononion japonicum, Pullenia bulloides, Pullenia quinqueloba, Reussoolina laevis, Siphogenerina columellaris, Sphaeroidina bulloides, Stainforthia fusiformis, Trifarina angulosa, Trifarina bradyi, Uvigerina asperula, Uvigerina auberiana, Uvigerina canariensis, Uvigerina cushmani, Uvigerina peregrina, Valvulineria bradyana.

Oxia indicators $\left(\mathrm{O}_{2}>1.5 \mathrm{ml} / \mathrm{l}\right)$ : Adelosina longirostra, Adelosina pulchella, Bulimina truncana, Cibicides refulgens, Cibicidoides wuellerstorfi, Cibicidoides pachyderma, Cibicidoides pseudoungeriana, Globocassidulina crassa, Globocassidulina subglobosa, Pyrgo bulloides, Pyrgo denticulata, Pyrgo elongata, Pyrgo ringens, Pyrgo laevis, Pyrgo lucernula, Pyrgo murrhina, Pyrgo williamsoni, Quinqueloculina lamarckiana, Quinqueloculina lata, Quinqueloculina seminula, Sigmopyrgo vespertilio, Triloculina tricarinata, Triloculina trigonula, Triloculina oblonga.

Appendix 2. Benthic foraminifera coastal species present in core PP10-12. The list includes species living in coastal and estuarine settlements of Bay of Biscay (PujosLamy, 1973; Cearreta, 1988, 1989; Pascual and Rodríguez-Lázaro, 2006, Pascual et al., 2008, 2019; Martínez-García et al., 2013).

Ammonia beccarii, Asterigerinata mamilla, Cibicidoides lobatulus, Cribroelphidium excavatum, Cribroelphidium gerthi, Elphidium articulatum, Elphidium crispum, Entzia macrescens, Haynesina depressula, Miliolinella circularis, Miliolinella elongata, Miliolinella subrotunda, Nonion commune, Planorbulina mediterranensis, Porosononion granosum, Quinqueloculina seminula, Quinqueloculina lata, Rosalina globularis Rosalina irregularis, Rosalina williamsoni, Triloculina oblonga, Trochammina inflata

\section{References}

Abu-Zied, R. H., Rohling, E. J., Jorissen, F. J., Fontanier, C., Casford, J. S. L., Cooke, S., 2008. Benthic foraminiferal response to changes in bottom-water oxygenation and 
organic carbon flux in the eastern Mediterranean during LGM to Recent times. Marine Micropaleontology. 67(1-2), 46-68.https://doi:10.1016/j.marmicro.2007.08.006

Alavi, S.N., 1988. Late Holocene deep-sea benthic foraminifera from Sea of Marmara. Marine Micropalaeontology. 13, 213-237.

Alley, R.B., Ágústsdóttir, A.M., 2005. The 8k event: cause and consequences of a major Holocene abrupt climate change. Quaternary Sci. Rev. 24, 1123e 1149.

DOI:10.1016/j.quascirev.2004.12.004

Altenbach, A.V., 1988. Deep sea benthic foraminifera and flux rate of organic carbon. Rev. Paléobiologie. Vol. Spec. 2, 719-720.

Alve, E., Bernhard, J.M., 1995. Vertical migratory response of benthic foraminifera to controlled oxygen concentrations in an experimental mesocosm. Marine Ecology. Progress Series.116, 137-151.

Angue Minto'o, C.M., Bassetti M.-A., Toucanne, S., Jouet, G., 2016. Distribution of ostracod and benthic foraminiferal assemblages during the last $550 \mathrm{kyr}$ in the EastCorsica basin, western Mediterranean Sea: A paleo-environmental reconstruction. Revue de Micropaléontologie. 59 (2), 83-96-

https://doi.org/10.1016/j.revmic.2016.01.002

Baas, J.H., Schönfeld, J., Zahn, R., 1998. Mid-depth oxygen drawdown during Heinrich Events: Evidence from benthic foraminiferal community structure, trace fossil tiering, and benthic $\square 13 \mathrm{C}$ at the Portuguese Margin. Mar. Geol. 152(1-3), 25-55. http://dx.doi.org/10.1016/S0025-3227(98)00063-2

Bard, E., Hamelin, B., Delanghe-Sabatier, D., 2010. Deglacial Meltwater Pulse 1B and Younger Dryas Sea Levels Revisited with Boreholes at Tahiti. Science. 327, 12351237. DOI:10.1126/science. 1180557

Bernhard J.M., Sen Gupta B.K., 1999. Foraminifera of oxygen-depleted environments. in: Sen Gupta B.K. (Ed.), Modern Foraminifera. Kluwer Academic Publishers .Springer, Dordrecht, pp. 201-216.

Boltovskoy, E., Wright, R., 1976. Recent Foraminifera, ed. Dr. Junk, The Hague, The Netherlands. 
Caralp, M., Lamy, A., Pujos, M., 1970. Contribution a la connaissance de la distribution bathymetrique des foraminiferes dans le Golfe de Gascogne. Revista Española de Micropaleontología. 2, 55-84.

Carlson, A.E., Clark, P.U., 2012. Ice sheet sources of sea level rise and freshwater discharge during the last deglaciation. Reviews of Geophysics. 50(4),1944-9208, RG4007, doi:10.1029/2011RG000371

Castaño-Carrera, M., Pardo P.C., Álvarez, M., Lavín A, Rodríguez, C., Carballo, R., Ríos, A.F., 2012. Anthropogenic carbon and water masses in the Bay of Biscay. Ciencias Marinas. 38, 191-207. http://dx.doi.org/10.7773/cm.v38i1B.1820

Cearreta, A., 1988. Distribution and ecology of benthic foraminifera in the Santoña estuary. Rev. Esp. Paleontol. 3, 23-38.

Cearreta, A., 1989. Foraminiferal assemblages in the ria of San Vicente de la Barquera (Cantabria, Spain). Rev. Esp. Micropaleontol. XXI (1), 67-80.

Charria, G., Lazure, P., Le Cann, B., Serpette, A., Reverdin, G.,Louazel, S., Batifoulier, F., Dumas, F., Pichon, A., Morel, Y., 2013 Surface layer circulation derived from Lagrangian drifters in the Bay of Biscay, J. Marine Syst. 109-110, S60-S76. https://doi:10.1016/j.jmarsys.2011.09.015

Corliss, B.H.,1991. Morphology and microhabitat preferences of benthic foraminifera from the northwest Atlantic Ocean. Marine Micropaleontology. 17, 195-236. https://doi.org/10.1016/0377-8398(91)90014-W

Corliss, B.H., Emerson, S., 1990. Distribution of Rose Bengal stained deep-sea benthic foraminifera from the Nova Scotian continental margin and Gulf of Maine. Deep-Sea Research. 37, 381-400. https://doi.org/10.1016/0198-0149(90)90015-N

De Rijk, S., Troelstra, S.R., Rohling, E.J., 1999. Benthic foraminiferal distribution in the Mediterranean Sea. J. Foraminifer Res. 29, 93-103.

https://doi.org/10.2113/gsjfr.29.2.93 
Debenay, J.P., Konate, S., 1987. Les Foraminifères actuéls des iles de Los (Guinée). Premier inventaire, comparaison avec les microfaunes voisines. Rev. Paléobiologie. 6 , 213-227.

Diz, P., Francés, G., Roson, G., 2006. Effects of contrasting upwelling-downwelling on benthic foraminiferal distribution in the Ria de Vigo (NW Spain). Journal of Marine Systems. 60, 1-18. DOI: 10.1016/.j.jmarsys.2005.11.001

Duchemin, G., Jorissen, F.J., Le Loc'H, F., Andrieux-Loyer, F., Hily, C., Thouzeau, G., 2008. Seasonal variability of living benthic foraminifera from the outer continental shelf of the Bay of Biscay. Journal of Sea Research. 59, 297-319.

doi:10.1016/j.seares.2008.03.006

Ernst, S., Duijnstee, I., Fontanier, C., Jorissen, F., van der Zwaan, B., 2008. A comparison of foraminiferal infaunal distributions in field and experimental samples from 550-m depth in the Bay of Biscay. Deep-Sea Research Part I. 55, 498-518. DOI:10.1016/j.dsr.2008.01.003

Esnaola, G., Sáenz, J., Zorita, E., Fontán, A., Valencia, V., Lazure, P., 2013. Daily scale wintertime sea surface temperature and IPC-Navidad variability in the southern Bay of Biscay from 1981 to 2010, Ocean Sci., 9, 655-679.

https://doi:10.5194/os-9-655-2013

Fontanier, C., Jorissen, F.J., Licari, L., Alexandre, A., Anschutz, P., Carbonel, P., 2002. Live benthic foraminiferal faunas from the Bay of Biscay; faunal density, composition and microhabitats. Deep-Sea Research I. 49(4), 751-785. http://dx.doi.org/10.1016/S0967-0637(01)00078-4

Fontanier, C., Jorissen, F.J., Chaillou, G., David, C., Anschutz, P., Lafon, V., 2003. Seasonal and interannual variability of benthic foraminiferal faunas at $550 \mathrm{~m}$ depth in the Bay of Biscay. Deep-Sea Res. I : Oceanogr. Res. Pap. 50(4), 457-494.

doi:10.1016/S0967-0637(02)00167-X

Fontanier, C., Jorissen, F.J., Chaillou, G., Anschutz, P., Grémare, A., Griveaud, C., 2005. Live foraminiferal faunas from a $2800 \mathrm{~m}$ deep lower canyon station from the Bay of Biscay: Faunal response to focusing of refractory organic matter. Deep-Sea Res. I: Oceanogr. Res. Pap. 52(7), 1189-1227. http://dx.doi.org/10.1016/j.dsr.2005.01.006 
Fontanier, C., Jorissen, F., Geslin, E., Zaragosi, S., Duchemin, G., Laversin, M., Gaultier, M., 2008. Live and dead foraminiferal faunas from Saint-Tropez Canyon (Bay of Frejus): observations based on in situ and incubated cores. J. Foraminifer. Res. 38 (2),137-156. http://dx.doi.org/10.2113/gsjfr.38.2.137

García, J., Mojtahid, M., Howa, H., Michel, E. 2013. Benthic and Planktic Foraminifera as Indicators of Late Glacial to Holocene Paleoclimatic Changes in a Marginal Environment: An Example from the Southeastern Bay of Biscay. Acta Protozoologica, 52, 161-180.

\section{DOI 10.4467/16890027AP.13.0015.1112}

García-Soto, C., Pingree, R. D., Valdés, L., 2002. Navidad development in the southern Bay of Biscay: Climate change and swoddy structure from remote sensing and in situ measurements, J. Geophys. Res., 107. https://doi:10.1029/2001JC001012

García-Soto, C., Pingree, R. D., 2012. Atlantic Multidecadal Oscillation (AMO) and sea surface temperature in the Bay of Biscay and adjacent regions, J. Mar. Biol. Assoc. UK. 92, 213-234. DOI: https://doi.org/10.1017/S0025315410002134

Geslin, E., Heinz, P., Jorissen, F., Hemleben, C., 2004. Migratory responses of deepsea benthic foraminifera to variable oxygen conditions: laboratory investigations, Mar. Micropaleontol. 53(3-4), 227-243. http://dx.doi.org/10.1016/j.marmicro.2004.05.010

Goineau, A., Fontanier, C., Jorissen, F. J., Lansard, B., Buscail, R., Mouret, A., Kerherv'e, P., Zaragosi, S., Ernoult, E., Art'ero, C., Anschutz, P., Metzger, E. Rabouille, C., 2011. Live (stained) benthic foraminifera from the Rhône prodelta (Gulf of Lion, NW Mediterranean): Environmental controls on a river-dominated shelf. DOI: 10.1016/i.seares.2010.07.007

Gottschalk, J., Skinner, L.C., Misra, S., Waelbroeck, C., Menviel, L., Timmermann, A. 2015. Abrupt changes in the southern extent of North Atlantic Deep Water during Dansgaard-Oeschger events. Nat. Geosci. 8, 950-955. http://dx.doi.org/ 10.1038/ngeo2558

Grunert, P., Skinner, L., Hodell, D.A., Piller, W.E., 2015. A micropalaeontological perspective on export productivity, oxygenation and temperature in NE Atlantic deep- 
waters across Terminations I and II. Glob. Planet. Change. 131, 174-191. http://dx.doi.org/10.1016/i.gloplacha.2015.06.002

Hammer, Ø., Harper, D.A.T., Ryan, P.D., 2001. PAST: Paleontological Statistics Software Package for Education and Data Analysis. Palaeontol. Electron. 4, 9.

Hayek, L.-A.C., Wilson, B., 2013. Quantifying Assemblage Turnover and Species Contributions at Ecologic Boundaries. PLoS ONE. 8(10), e74999.

http://dx.doi.org/10.1371/journal.pone.0074999

Healey, S.L., Thunell, R.C., Corliss, B.H., 2008. The Mg/Ca-temperature relationship of benthic foraminiferal calcite: New core-top calibrations in the $<4^{\circ} \mathrm{C}$ temperature range. Earth and Planetary Science Letters. 272, 523-530.

https://doi.org/10.1016/i.epsl.2008.05.023

Hess, S., Jorissen, F.J., 2009. Distribution patterns of living benthic foraminifera from Cap Breton canyon, Bay of Biscay: faunal response to sediment instability. Deep-Sea Res.I Oceanogr. Res. Pap. 56 (9), 1555-1578.

http://dx.doi.org/10.1016/j.dsr.2009.04.003

Holbourn, A., Henderson, A.S., Macleod, N., 2013. Atlas of benthic foraminifera, first ed. Wiley-Blackwell, London.

Jorissen, F.J., 1987. The distribution of benthic foraminifera in the Adriatic Sea. Marine Micropalaeontology. 12, 21-48. https://doi.org/10.1016/0377-8398(87)90012-0

Jorissen, F.J., 2003. Benthic foraminiferal microhabitats below the sediment-water inter-face. In: Sen Gupta, B.K. (Ed.), Modern Foraminifera. Kulwer Academic Publishers, New York, pp. 161-181.

Jorissen, F. J., Barmawidjaja, D. M., Puskaric, S., van der Zwaan, G. J., 1992. Vertical distribution of benthic foraminifera in the northern Adriatic Sea: The relation with the organic flux, Mar. Micropaleontol. 19, 131-146. https://doi.org/10.1016/0377-8398(92)90025-F Jorissen, F.J., Wittling, L., Peypouquet, J.P., Rabouille, C., Relexans, J.C., 1998. Live benthic foraminiferal faunas off Cape Blanc, NW Africa: community structure and 
microhabitats. Deep-Sea Res. I: Oceanogr. Res.45(12), 2157-2188. http://dx.doi.org/10.1016/S0967-0637(98)00056-9

Jorissen, F. J., Fontanier, C., Thomas, E., 2007. Paleoceanographical proxies based on deep-sea benthic foraminiferal assemblage characteristics, in: Hillaire-Marcel, C., De Vernal, A. (Eds.), Proxies in Late Cenozoic Paleoceanography: Pt. 2: Biological tracers and biomarkers. Elsevier, Amsterdam, pp. 263-326. http://dx.doi.org/10.1016/S1572-5480(07)01012-3

Kaiho, K., 1994. Benthic foraminiferal dissolved-oxygen index and dissolved-oxygen levels in the modern ocean. Geology. 22(8), 719-722. http://dx.doi.org/10.1130/00917613(1994)022<0719:BFDOIA>2.3.CO;2

Kaiho, K., 1999. Effect of organic carbon flux and dissolved oxygen on the benthic foraminiferal oxygen index (BFOI). Mar. Micropaleontol. 37(1), 67-76. http://dx.doi.org/10.1016/S0377-8398(99)00008-0

Kitazato, H., 1994. Foraminiferal microhabitats in four marine environments around Japan. Marine Micropaleontology. 24, 29-41. https://doi.org/10.1016/03778398(94)90009-4

Kuhnt, T., Schmiedl, G., Ehrmann, W., Hamann, Y., Hemleben, C., 2007. Deep-sea ecosystem variability of the Aegean Sea during the past $22 \mathrm{kyr}$ as revealed by Benthic Foraminifera. Marine Micropaleontology. 64, 141-162.

https://doi:10.1016/i.marmicro.2007.04.003

Langezaal, A.M., Jorissen, F.J., Braun, B., Chaillou, G., Fontanier, C., Anschutz, P., van der Zwaan, G.J., 2006. The influence of seasonal processes on geochemical profiles and foraminiferal assemblages on the outer shelf of the Bay of Biscay. Continental Shelf Research. 26,1730-1755. DOI:10.1016/j.csr.2006.05.005

Levy, A., Mathieu, R., Poignant, A., Rosset-Moulinier, M., Ubaldo, M.L., Lebreiro, S., 1995. Foraminifères actuels de la marge continentale portuguaise-inventaire et distribution. Mem. Inst. Geol. Min. Port. 32, 1-116.

Liu, Z., Otto-Bliesner, B. L., He, F., Brady, E. C., Tomas, R., Clark, P. U., Carlson, A. E., Lynch-Stieglitz, J., Curry, W., Brook, E., Erickson, D., Jacob, R., Kutzbach, J., Cheng, J., 2009. Transient Simulation of Last Deglaciation with a New Mechanism for Bølling-Allerød Warming, Science. 325(5938), 310-314. doi:10.1126/science.1171041 
Loeblich, A.R., Tappan, H., 1988. Foraminiferal Genera and Their Classification, ed. Van Nostrand Reinhold, New York.

Loncaric, N., Auffret, G.A., Abrantes, F., Baas, J.H., Gaspar, L., Pujol, C., 1998. Late Quaternary sedimentation patterns on the Meriadzek Terrace, Bay of Biscay (ESSCAMP 02 core: 47N, 9W). Marine Geology, 152(1 -3), 57-73. http://dx.doi.org/10.1016/S0025-3227(98)00064-4

Lozier, M. S., Stewart, N. M., 2008. On the Temporally Varying North-ward Penetration of Mediterranean Overflow Water and East-ward Penetration of Labrador Sea Water, J. Phys. Oceanogr., 38, 2097-2103. https://doi.org/10.1175/2008JPO3908.1

Lutze, G.F., 1986. Uvigerina species of the Eastern North Atlantic, in: Van der Zwaan, G.J., Jorissen, F.J, Verhallen, P., Daniels, C. (Eds.), Atlantic-European Oligocene to Recent Uvigerina. Utrecht Micropaleontological Bulletins. 35. University of Ultrecht, Ultrecht, pp. 21-46.

Mackensen, A., Douglas, R.G., 1989. Down-core distribution of live and dead deepwater benthic foraminifera in box cores from the Weddell Sea and the California continental borderland. Deep-Sea Research. 36, 879-900. https://doi.org/10.1016/0198-0149(89)90034-4

Mackensen, A., Schmiedl, G., Harloff, J., Giese, M.,1995. Deep-sea foraminifera in the South Atlantic Ocean: ecology and assemblage generation. Micropaleontol. 41(4), $342-$ 358. http://dx.doi.org/10.2307/1485808

McManus, J.F., Keigwin, L., Francois, R., Drown-Leger, S., Gherardi, J.M., 2004. Collapse and rapid resumption of Atlantic meridional circulation linked to deglacial climate changes. Nature. 428, 834- 837. doi:10.1038/nature02494

Martins, M.V.A., Ruivo Dragao Gomes, V.C. 2004. Foraminíferos da margem continental NW ibérica: sistemática, ecologia e distribuição. Ed., Agenda ComumComunicacao Ida. Universidade de Aveiro, Portugal.

Martínez-García, B.; Pascual, A., Rodríguez-Lázaro, J., Bodego, A., 2013. Recent benthic foraminifers of the Basque continental shelf (Bay of Biscay, Northern Spain): 
Oceanographic implications. Cont. Shelf Res. 66, 105-122.

http://dx.doi.org/10.1016/i.csr.2013.07.006

Martínez-García, B., Bodego, A., Mendicoa, J., Pascual, A., Rodríguez -Lázaro, J., 2014. Late Quaternary (Marine Isotope Stage 3 to Recent) sedimentary evolution of the Basque shelf (southern Bay of Biscay). Boreas. 43(4), 973-988.

https://doi.org/10.1111/bor.12079

Martínez-García, B., Rodríguez-Lázaro, J., Pascual, A., Mendicoa, J., 2015. The "Northern guests" and other paleoclimatic ostracod proxies in the late Quaternary of the Basque Basin (S Bay of Biscay). Palaeogeogr., Palaeoclimatol., Palaeoecol. 419, 100-114. http://dx.doi.org/10.1016/j.palaeo.2014.06.032

Martrat, B., Grimalt, J.O., Shackleton, N.J., de Abreu, L., Hutterli, M.A., Stocker, T.F., 2007. Four Climate Cycles of Recurring Deep and Surface Water Destabilizations on the Iberian Margin. Science, 317, 502-507. DOI: 10.1126/science.1139994

Mathieu, R., 1986. Sediments et foraminifères actuels de la Marge Continentale Atlantic du Maroc. These de Doctorat, Universite Pierre et Marie Curie, Paris.

Mary, Y., Eynaud, F., Colin, C., Rossignol, L., Brocheray, S., Mojtahid, M., García, J., Peral, M., Howa, H., Zaragosi, S., Cremer, M., 2017. Changes in Holocene meridional circulation and poleward Atlantic flow: the Bay of Biscay as a nodal point. Clim. Past, 13, 201-216, https://doi.org/10.5194/cp-13-201-2017

Mendes, L., González, R., Lobo, F., Dias, J.M.A., Martins, V., 2004. Factors influencing recent benthic foraminifera distribution on the Guadiana shelf (Southwestern Iberia). $\begin{array}{llr}\text { Mar } & \text { Micropaleontol. } & \text { 51(1-2), }\end{array}$ http://dx.doi.org/10.1016/j.marmicro.2003.11.001

Moodley, L., van der Zwaan, G.J., Rutten, G.M.W., Boom, R.C.E., Kempers, A.J,. 1998. Subsurface activity of benthic foraminifera in relation to porewater oxygen content: laboratory experiments. Marine Micropaleontology. 34, 91-106. https://doi.org/10.1016/S0377-8398(97)00044-3

Mojtahid, M., Griveaud, C., Fontanier, C., Anschutz, P., Jorissen, F.J., 2010. Live benthic foraminiferal faunas along a bathymetrical transect (140-4800 m) in the Bay of 
Biscay (NE Atlantic). Revue de Micropaléontologie. 53. 139-162.

https://doi:10.1016/j.revmic.2010.01.002

Morley, A., Rosenthal, Y., de Menocal, P., 2014. Ocean-atmosphere climate shift during the mid-to-late Holocene transition, Earth Planet. Sc. Lett., 388, 18-26, https://doi:10.1016/j.epsl.2013.11.039

Mulder T., Zaragosi S., Garlan T., Mavel J., Cremer M., Sottolichio A., Senechal N., Schmidt S., 2012. Present deep-submarine canyons activity in the Bay of Biscay (NE Atlantic), Marine Geology. 295-298, 113-127. doi:10.1016/j.margeo.2011.12.005

Murray, J.W. (1973). Distribution and Ecology of Living Benthic Foraminiferids. Heinemann, London, United Kingdom.

Murray, J.W., 1976. A method of determining proximity of marginal seas to an ocean. Marine Geology. 22(2), 103-119.

Murray, J.W., 1991. Ecology and palaeoecology of benthic foraminifera, first ed. Longman, Harlow.

Murray, J.W., 2006. Ecology and Applications of Benthic Foraminifera, first ed. Cambridge University Press, Cambridge.

Naughton, F., Sánchez Goñii, M.F., Kageyama, M., Bard, E., Cortijo, E., Desprat, S.,Duprat, J., Malaizé, B., Joli, C., Rostek, F., Turon, J.L., 2009. Wet to dry climatic trend in north western Iberia within Heinrich events. Earth and PlanetaryScience Letters. 284, 329-342.

Naughton, F., Sanchez-Goñi, M.F., Rodrigues, T., Salgueiro, E., Costas S., Desprat, S., Duprat, J., Michel, E., Rossignol, L., Zaragosi, S., Voelker, A.H.L., Abrantes, F. 2016. Climate variability across the last deglaciation in NW Iberia and its margin. Quat. Int. 414, 9-22. http://dx.doi.org/10.1016/j.quaint.2015.08.073

Obase, T., Abe-Ouchi, A., 2019.Abrupt Bølling-Allerød warming simulated under gradual forcing of the last deglaciation. Geophysical Research Letters. 46 https://doi.org/10.1029/ 
Obbink, E.A., Carlson, A.E., Klinkhammer, G.P., 2010. Eastern North American freshwater discharge during the Bolling-Allerod warm periods. Geology. 38, 171-174. https://doi.org/10.1130/G30389.1

Pascual, A., Rodríguez-Lázaro, J., 2006. Marsh development and sea level changes in the Gernika Estuary (southern Bay of Biscay): foraminifers as tidal indicators. Sci. Mar. 70S1, 101-117.

Pascual, A., Rodríguez-Lázaro, J., Martín-Rubio, M., Jouanneau, J.-M., Weber, O., 2008. A survey of the benthic microfauna (foraminifera, Ostracoda) on the Basque shelf, southern Bay of Biscay. J. Mar. Syst. 72(1-4), 35-63.

http://dx.doi.org/10.1016/j.jmarsys.2007.05.015

Pascual, A., Martínez-García, B., Mendicoa, J., 2019. Benthic foraminifers as a proxy of the range of the tidal wave in the Oyambre Estuary (Cantabria, Spain). Continental Shelf Research. 176 . pp. 1-18. https://doi.org/10.1016/j.csr.2019.02.008

Patarroyo, G.D., Martínez, J.I., 2016. Paleoxigenación y paleoproductividad en el golfo de Panamá durante el Holoceno tardío. Bol. Geolog. 38(2), 75-92.

http://dx.doi.org/10.18273/revbol.v38n2-2016005

Peliz, Á., Dubert, J., Santos, A. M. P., Oliveira, P. B., Le Cann,B., 2005. Winter upper ocean circulation in the Western Iberian Basin Fronts, Eddies and Poleward Flows: an overview. Deep-Sea Res.Pt. I. 52, 621-646. https://doi:10.1016/j.dsr.2004.11.005

Penaud, A., Eynaud, F., Turon, J. L., Zaragosi, S., Malaizé, B., Toucanne, S., Bourillet, J. F. 2009. What forced the collapse of European ice sheets during the last two glacial periods (150 ka B.P.and 18 ka cal B.P.)? Palynological evidence. Palaeogeography, Palaeoclimatology, Palaeoecology. 281, 66-78. doi:10.1016/j.palaeo.2009.07.012

Pingree, R., 2005. North Atlantic and North Sea climate change: curl up, shut down, NAO and ocean colour, J. Mar. Biol. Assoc. UK. 85, 1301-1315. DOI: https://doi.org/10.1017/S0025315405012488

Pingree, R. D., García-Soto, C., 2014. Plankton blooms, ocean circulation and the European slope current: Response to weather and climate in the Bay of Biscay and W 
English Channel (NE Atlantic), Deep-Sea Res. Pt. II. 106, 5-22.

https://doi.org/10.1016/i.dsr2.2014.07.008

Pujos-Lamy, A. (1973). Repartition bathymetrique des foraminiferes benthiques du Golfe de Gascogne. Comparaison avec d'autres aires oceaniques. Revista Española de Micropaleontología.5, 213-234.

Rahmstorf, S., Box, J.E., Feulner, G., Mann, M.E., Robinson, A, Rutherford, S., Schaffernicht, E. J., 2015. Exceptional twentieth-century slowdown in Atlantic Ocean overturning circulation. Nature Climate Change. 5 (5), 475-480.

https://doi.org/10.1038/nclimate2554

Rai A.K., Singh V.B., 2012. Response of eastern Indian Ocean (ODP Site 762B) benthic foraminiferal assemblages to the closure of the Indonesian seaway. Oceanologia. 54(3), 449-472. https://doi.org/10.5697/oc.54-3.449

Rasmussen, T.L., Thomsen, E., Troelstra, S.R., Kuijpers, A., Prins, M.A., 2002. Millennial-scale glacial variability versus Holocene stability: changes in planktic and benthic foraminifera faunas and ocean circulation in the North Atlantic during the last 60000 years. Marine Micropaleontology. 47(1-2), 143-176.

http://dx.doi.org/10.1016/S0377-8398(02)00115-9

Rasmussen, S.O., Bigler, M., Blockley, S.P., Blunier, T., Buchardt, S.L., Clausen, H.B., Cvijanovic, I, Dahl-Jensen, D., Johnsen, S.J., Fischer, H., Gkinis, V.,Guillevic, M., Hoek, W.Z., Lowe, J.J., Pedro, J.B., Popp, T., Seierstad, I.K., Steffensen, J.P., Svensson, A.M., Vallelonga, P., Vinther, B.M., Walker, M.J.C., Wheatley, J.J., Winstrup, M., 2014. A stratigraphic framework for abrupt climatic changes during the Last Glacial period based on three synchronized Greenland ice-core records: refining and extending the INTIMATE event stratigraphy. Quaternary Science Reviews. 106, 14-28. https://doi.org/10.1016/j.quascirev.2014.09.007

Rathburn, A.E., Corliss, B.H., 1994. The ecology of living (stained) deep-sea benthic foraminifera from the Sulu Sea. Paleoceanography. 9, 87-150.

https://doi.org/10.1029/93PA02327 
Reimer, P. J., Baillie, M. G. L., Bard, E., Bayliss, A., Beck, J. W.,Blackwell, P. G., Bronk Ramsey, C., Buck, C. E., Burr, G. S.,Edwards, R. L., Friedrich, M., Grootes, P. M., Guilderson, T. P.,Hajdas, I., Heaton, T. J., Hogg, A. G., Hughen, K. A., Kaiser, K.F., Kromer, B., McCormac, F. G., Manning, S. W., Reimer, R.W., Richards, D. A., Southon, J. R., Talamo, S., Turney, C. S. M., van der Plicht, J., Weyhenmeyer, C. 2009. IntCal09 and Marine09 radiocarbon age calibration curves, 0-50,000 years cal BP. Radiocarbon. 51, 1111-1150. https://doi.org/10.1017/S0033822200034202

Reißig, S., Nürnberg, D., Bahr, A., Poggemann, D.-W., Hoffmann, J., 2019. Southward displacement of the North Atlantic subtropical gyre circulation system during North Atlantic cold spells. Paleoceanography and Paleoclimatology. 34, 866-885. https://doi.org/10.1029/2018PA003376

Rodríguez-Lázaro, J., Pascual, A., Cacho, I., Varela, Z., Pena, L.D., 2017. Deep-sea benthic response to rapid climatic oscillations of the last glacial cycle in the SE Bay of Biscay. Journal of Sea Research. 130, 49-72. https://doi.org/10.1016/j.seares.2017.06.002

Rosenthal,Y., Morley, A., Barras, C., Katz, M.E., Jorissen, F., Reichart, G.-J., Oppo, D. W., Linsley, B. K., 2011. Temperature calibration of $\mathrm{Mg} / \mathrm{Ca}$ ratios in the intermediate water benthic foraminifer Hyalinea balthica, Geochem. Geophys. Geosyst.12, Q04003. https://doi.org/10.1029/2010GC003333

Ross, C.R., 1984. Hyalinea balthica and its late Quaternary paleoclimatic implications: Strait of Sicily.Journal of Foraminiferal Research. 14, 134-139.

Schmiedl, G., Bovee, E., Buscail, R., Charriere, B., Hemleben, C., Medernach, L., Picon, P., 2000. Trophic control of benthic foraminiferal abundance and microhabitat in the bathyal Gulf of Lions, western Mediterranean Sea. Marine Micropaleontology. 40,167-188.

DOI 10.1016/S0377-8398(00)00038-4 
Schnitker, D., 1979. The deep waters of the western North Atlantic during the past 24000 years, and the re-iniciation of the Western Boundary Undercurrent. Marine Micropaleontology. 4, 265-280. https://doi.org/10.1016/0377-8398(79)90020-3

Schönfeld, J., 2001. Benthic foraminifera and pore-water oxygen profiles: a reassessment of species boundary conditions at the western lberian margin. J. Foraminifer.Res. 31(2), 86-107. http://dx.doi.org/10.2113/0310086

Seierstad, I.K., Abbott, P.M., Bigler, M., Blunier, T., Bourne, A.J., Brook, E., Buchardt, S.L., Buizert, C., Clausen, H.B., Cook, E., Dahl-Jensen, D., Siwan M. Davies, S.M., Guillevic, M., Johnsen, S.J., Pedersen, D.S., Popp, T.P, Rasmussen, S.O., Severinghaus, J.P., Anders Svensson, A., Vinther, B.M., 2014. Consistently dated records from the Greenland GRIP, GISP2 and NGRIP ice cores for the past 104 ka reveal regional millennial-scale $\delta 180$ gradients with possible Heinrich event imprint. Quaternary Science Reviews. 106, 29-46. http://dx.doi.org/10.1016/i.quascirev.2014.10.032

Seiglie, G.A., 1968. Foraminiferal assemblages as indicators of organic carbon content or of water pollution Am. Assoc. Pet. Geol. 52, 2231-2241.

Sen Gupta B.K., Lee, R.F., May, M.S., 1981. Upwelling and an unusual assemblage of benthic foraminifera on the northern Florida continental slope. Journal of Paleontology. 55,853-857.

Shackleton, N.J., 2001. $\square 180$ (planktic foraminifera) of sediment core MD95-2042. PANGAEA. 58229. http://doi.pangaea.de/10.1594

Singh, A.D., Rai, A.K., Tiwari, M., Naidu, P.D., K. Verma, M. Chaturvedi, A. Niyogi, D. Pandey (2015). Fluctuations of Mediterranean Outflow Water circulation in the Gulf of Cadiz during MIS 5 to 7: Evidence from benthic foraminiferal assemblage and stable isotope records. Glob. Planet. Change. 133, Pages 125-140.

http://dx.doi.org/10.1016/i.gloplacha.2015.08.005

Stigter, H.C. de; Jorissen, F.J. y van der Zwaan, G.J. (1998). Bathymetric distribution and microhabitat partitioning of live (rose Bengal stained) benthic foraminifera along a shelf to bathyal transect in the southern Adriatic Sea. Journal of Foraminiferal Research. 28, 40-65. 
Stuiver, M., Reimer, P. J., 1993. Extended ${ }^{14} \mathrm{C}$ database and revised CALIB $3.0{ }^{14} \mathrm{C}$ Age Calibration Program. Radiocarbon, 35, 215-230. DOI:

https://doi.org/10.1017/S0033822200013904

Stuiver, M., Reimer, P. J., Reimer, R. W., 2005. CALIB 5.0. Available

at: http://calib.qub.ac.uk/calib/.

Toucanne, S., Zaragosi, S., Bourillet, J.F., Naughton, F., Cremer,M., Eynaud, F., Dennielou, B., 2008. Activity of the turbidite levees of the Celtic-Armorican margin (Bay of Biscay) during the last 30,000 years: Imprints of the last European deglaciation and Heinrich events. Mar. Geol. 247(1-2), 84-103.

http://dx.doi.org/10.1016/j.margeo.2007.08.006

Toucanne, S., Zaragosi, S., Bourillet, J.F., Cremer, M., Eynaud, F., van Vliet-Lanoe, B., Penaud, A., Fontanier, C., Turon, J.L., Cortijo, E., Gibbard, P.L., 2009. Timing of massive 'Fleuve Manche' discharges over the last 400 kyr: insights into the European Ice Sheet oscillations and the European drainage network from MIS 10 to 2.

Quaternary Science Reviews. 28 (13-14), 1238-1256.

https://doi.org/10.1016/j.quascirev.2009.01.006

Thornalley, D. J. R., Elderfield, H., McCave, I. N., 2009. Holocene oscillations in temperature and salinity of the surface subpolar North Atlantic, Nature, 457, 711-714. DOI: $10.1038 /$ nature 07717

Van der Zwaan, G.J., Jorissen, F.J., De Stigter,, H.C. 1990. The Depth-Dependency of Planktonic/Benthic Foraminiferal Ratios; Constraints and Applications. Marine Geology, 95, 1-16. http://dx.doi.org/10.1016/0025-3227(90)90016-D

Van der Zwaan, G.J., Jorissen, F.J., 1991. Biofacial patterns in river-induced shelf anoxia, in: Tyson, R.V., Pearson,T.H. (Eds.), Modern and Ancient Continental Shelf Anoxia. Geological Society of London Special Publications, 58, pp. 65-82.

Van Hinsbergen van, D.J.J., Kouwenhoven, T.J., van der Zwaan, G.J., 2005.

Paleobathymetry in the backstripping procedure: Correction for oxygenation effects on depth estimates. Palaeogeography, Palaeoclimatology, Palaeoecology, 221, 245-265. https://doi.org/10.1016/j.palaeo.2005.02.013 
WoRMS Editorial Board, 2019. http://www.marinespecies.org/foraminifera

Zaragosi, S., Eynaud, F., Pujol, C., Auffret, G.A., Turon, J.L., Garlan, T., 2001. Initiation of the European deglaciation as recorded in the northwestern Bay of Biscay slope environments (Meriadzek Terrace and Trevelyan Escarpment): A multi-proxy approach. Earth Planet. Sci. Lett. 188(3-4), 493-507. http://dx.doi.org/10.1016/S0012$\underline{821 \times(01) 00332-6}$

\section{FIGURE CAPTIONS}

Figure 1. A) Location of study area with indication of core PP10-12 (white circle), general oceanic circulation (IPC, Iberian Poleward Current; Navidad Current; NAC, North Atlantic Circulation; ESC, European Slope Current). Yellow discontinuous line indicates the profile of Fig. 1B. B) Main water masses (ENACW Atlantic Central Water; MOW, Mediterranean Outflow Water; NEADW $\mathrm{N}_{\mathrm{U}}$, North East Atlantic Deep Water upper component; NEADW , North East Atlantic Deep Water lower component; AABW, Antarctic Bottom Water) of the Bay of Biscay. Map modified from Mulder et al. (2012); water masses modified from Castaño-Carrera et al. (2012).

Figure 2. Chronostratigraphy of core PP10-12 based on correlation of percentage of Neogloboquadrina pachyderma sin (Npsin) with marine reference core MD95-2042 and ice core NGRIP-GICC05 (2014-12-10 version). Little arrows indicate AMS ${ }^{14} \mathrm{C}$ dates. Tie-points correspond to Heinrich events $(H)$, Greenland stadials (GS), Greenland interstadials (GI), Holocene Cooling Events (HCE) and other warm/cold events registered in Table 1. Grey dashed lines indicate interpretative tie-points. Ages of events from Rasmussen et al. (2014) and Gottschalk et al. (2015). LGM, Last Glacial Maximun; BA, Bølling-Allerød; YD, Younger Dryas; LH, Lower Holocene (Green., Greenlandian); MH, Middle Holocene (North., Northgrippian); UH, Upper Holocene (Megh., Meghalayan).

Figure 3. Age model of core PP10-12 based on 11 dates, 29 tie-points and 11 interpretative tie-points (Table 1). A) Age/core depth correlation (cm) with stratigraphic units (MIS3 to MIS1, with H1, GI1, B/A and Holocene sub-units). Cold Heinrich Events 
and Younger Dryas are in grey. Blue stars are AMS ${ }^{14} \mathrm{C}$; orange rectangles, tie-points from core NGRIP; green circles, tie-points from core MD95-2042; black rectangles and circles, interpretative tie-points from cores NGRIP and MD95-2042, respectively. B) Age/core depth non-linear logistic analysis of core PP10-12 (rectangles, interpretative tie-points). Correlation $r^{2}=0.98$, calculated with PAST software (Hammer et al., 2001). Acronyms as in Fig. 2.

Figure 4. Occurrence of benthic foraminifera species number (S), and percentages of coastal species, altered specimens and Oceanity Index of core PP10-12. In top of figure main chronostratigraphic units and limits are indicated. $\mathrm{H}$, Heinrich Events. Figure bottom with tie-points (black) and interpretative tie-points (grey) identified in the age model (see Table 1). Green, Holocene Cooling Events; orange, Greenland interstadials; blue, Greenland stadials and Heinrich Events $(H)$. Ages of events from Rasmussen et al. (2014) and Gottschalk et al. (2015). Acronyms as in Fig. 2.

Figure 5. Distribution of benthic foraminifera assemblages characteristic of oxygen level in sediments (Oxic, Suboxic, Dysoxic) in core PP10-12. Details in Table 3. Legend as in Fig. 4.

Figure 6. Distribution of percentages of main benthic foraminifera of core PP10-12. Legend as in Fig. 4.

\section{CAPTIONS OF TABLES}

Table 1. Calibrated ages used for the age model of core PP10-12 and tie-points identified as indicated in Fig. 2.

Table 2. Benthic foraminifera species identified from core PP10-12.

Table 3. Ecological preferences of most characteristic benthic foraminifera species used as proxy for deep-sea changes in core PP10-12. 



\section{Oka BP}

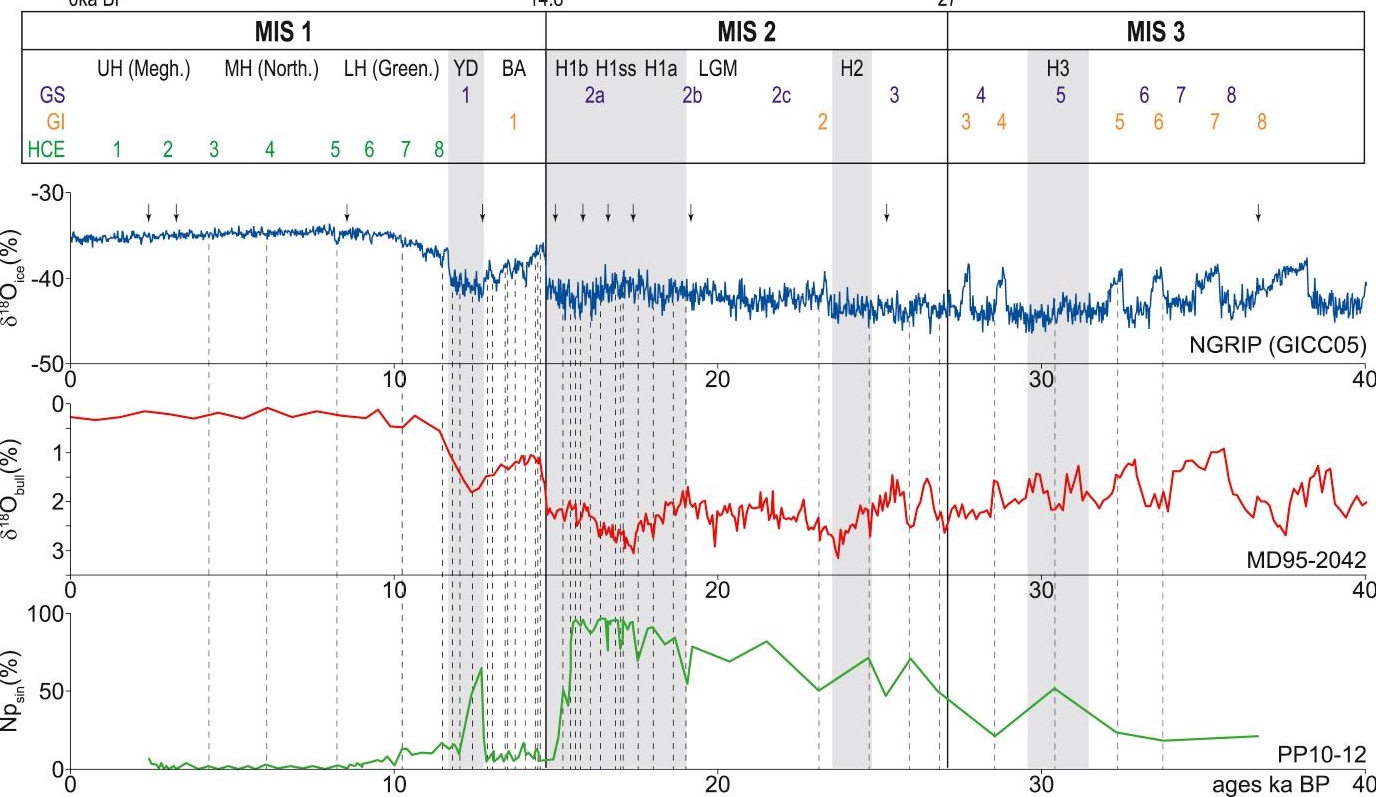




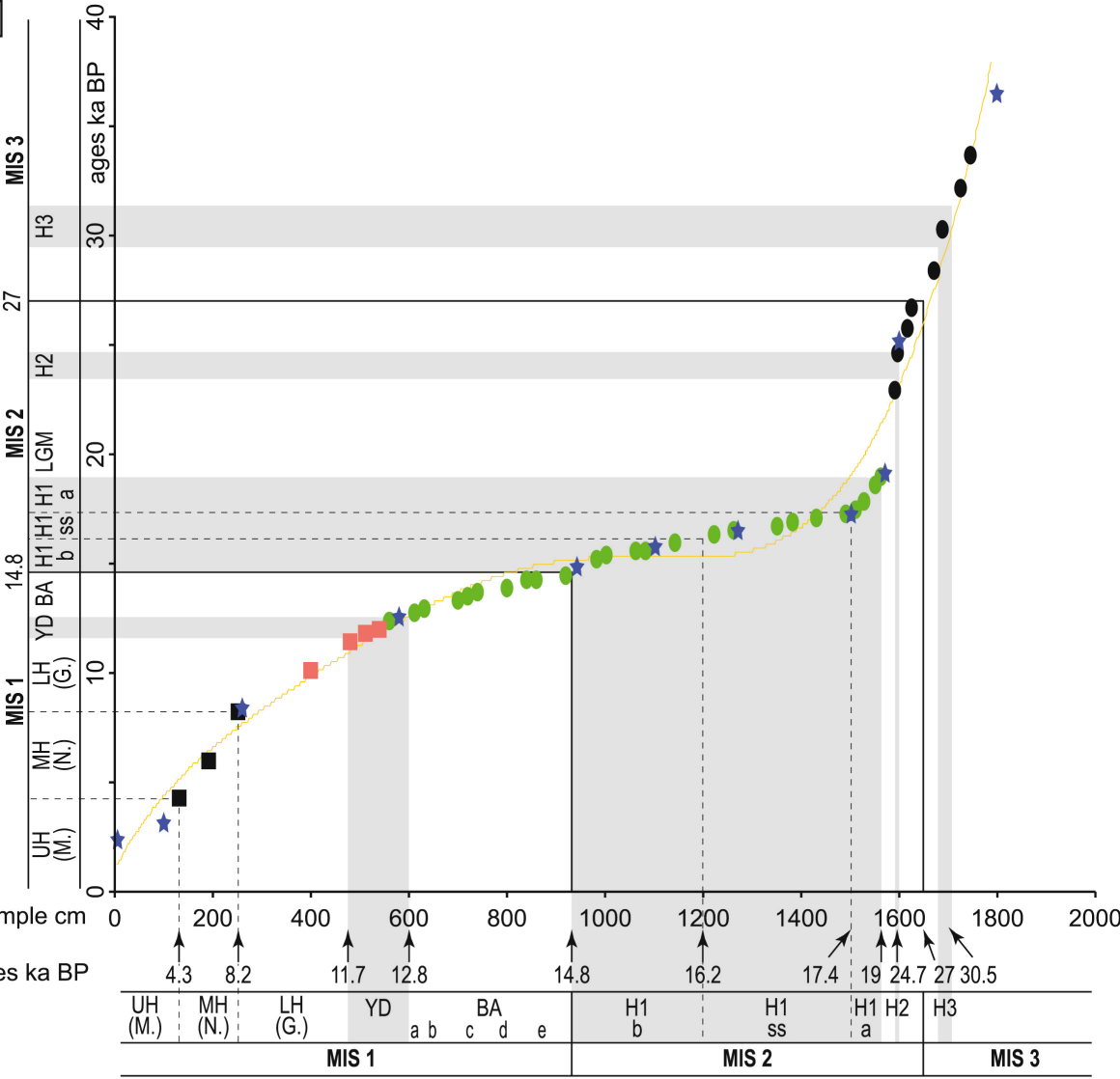

$B$

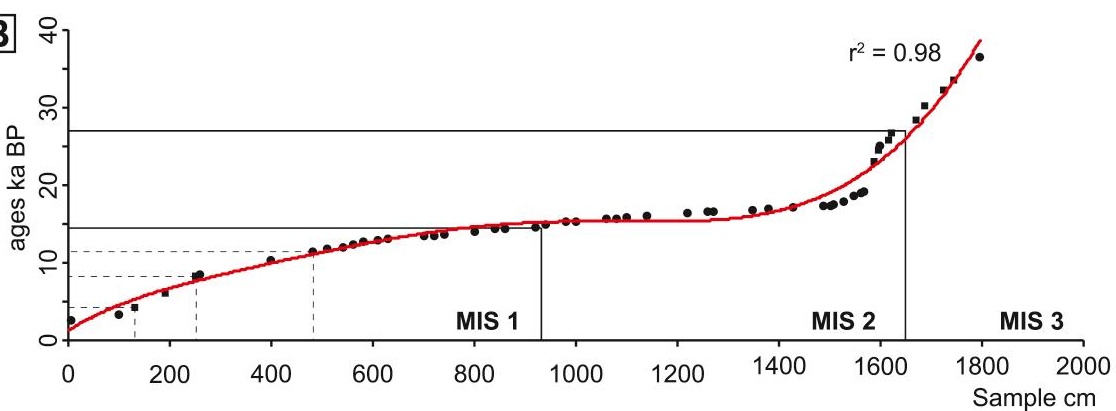

$\mathbf{A}$

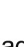

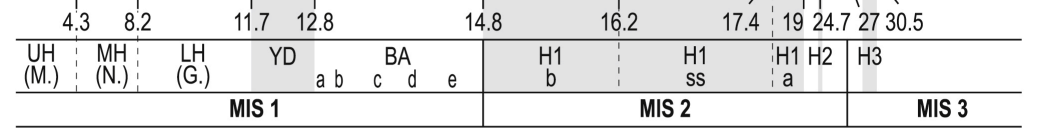




\section{Oka BP}

4.3

\section{MIS 1}

11.712 .8

\section{MIS 3}

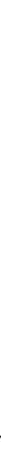




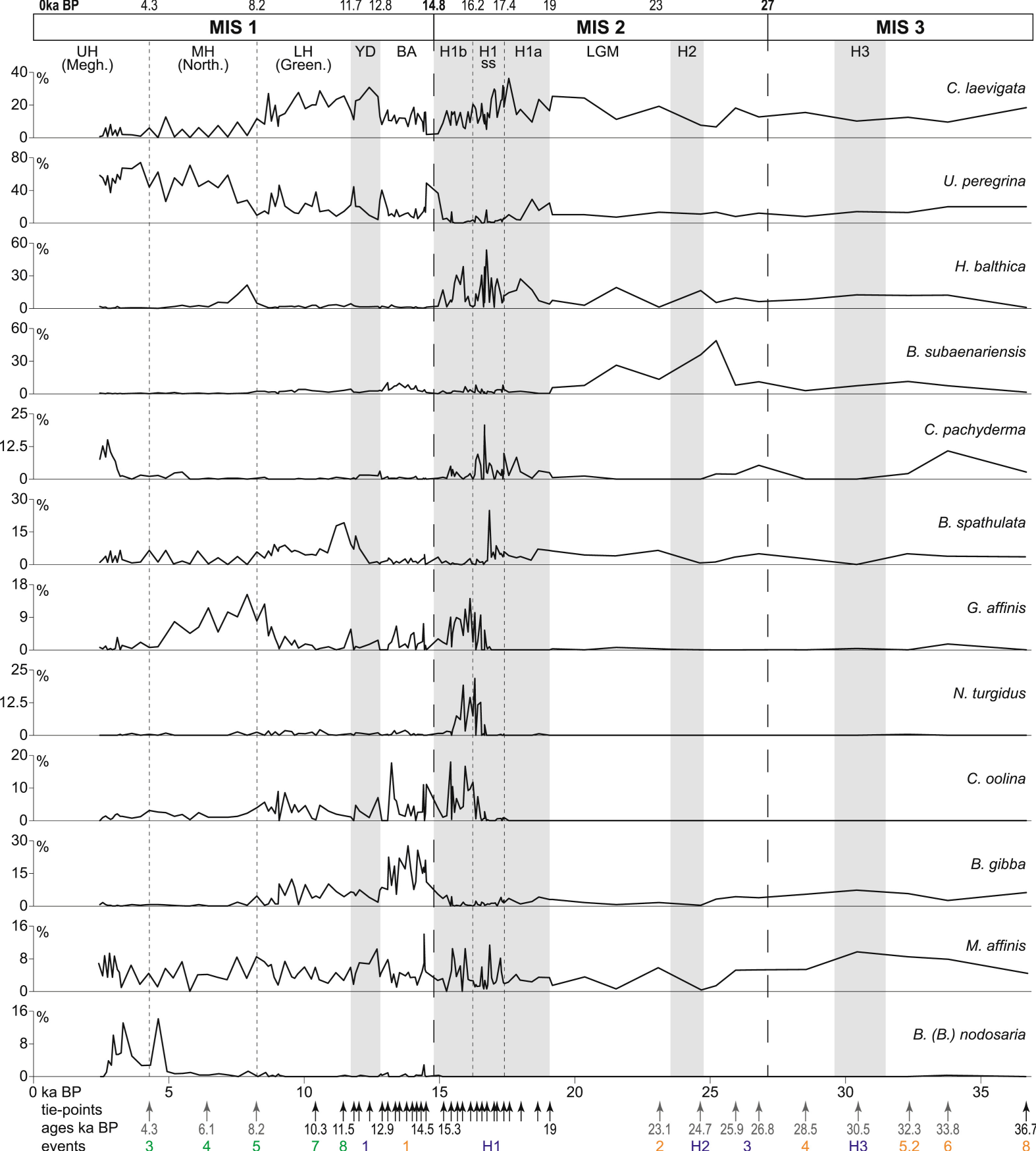




\section{SUPPLEMENTARY MATERIAL}

Benthic foraminifera species from core PP10-12 used in this work and counting for more than $10 \%$ of individuals in at least 3 samples. Number of specimens and species per sample, Oceanity Index (OI), number of altered tests and thanathocenotic coastal individuals are indicated. The number of specimens indicative of oxygen level (dysoxia, suboxia, oxia) is also depicted. 


$\begin{array}{cccc}\begin{array}{c}\text { core depth } \\ (\mathrm{cm})\end{array} & \begin{array}{c}{ }^{14} \mathrm{C} \text { age (yrs BP) } \\ \text { Calibrated date } \\ 2 \delta \text { range (cal. } \\ \text { yrs BP) }\end{array} & \begin{array}{c}\text { Calibrated date } \\ \text { (cal. yrs BP) } \\ \text { mean probability }\end{array} \\ 7 & 2730+/-30 & 2331-2574 & 2430 \\ 101 & 3400+/-30 & 3174-3356 & 3270 \\ 261 & 8080+/-30 & 8437-8617 & 8540 \\ 581 & 11230+/-40 & 12608-12823 & 12710 \\ 941 & 13000+/-50 & 14681-15175 & 14960 \\ 1096 & 13600+/-40 & 15695-16037 & 15860 \\ 1276 & 14180+/-50 & 16405-16910 & 16650 \\ 1501 & 14680+/-40 & 17193-17562 & 17400 \\ 1570 & 16320+/-50 & 18999-19401 & 19190 \\ 1600 & 21300+/-80 & 24973-25507 & 25230 \\ 1797 & 33160+/-210 & 36183-37536 & 36710\end{array}$

\begin{tabular}{|c|c|c|c|}
\hline $\begin{array}{l}\text { core depth } \\
\quad(\mathrm{cm})\end{array}$ & $\begin{array}{c}\text { Date calendar } \\
\text { age (yrs BP) }\end{array}$ & Event & $\begin{array}{c}\text { Stratigraphic } \\
\text { correlation }\end{array}$ \\
\hline 131 & 4280 & HCE3 & NGRIP \\
\hline 191 & 6080 & HCE4 & NGRIP \\
\hline 251 & 8260 & HCE5 & NGRIP \\
\hline 401 & 10280 & HCE7 & NGRIP \\
\hline 481 & 11480 & HCE8 & NGRIP \\
\hline 511 & 11840 & $\begin{array}{l}\text { inter-YD cold } \\
\text { event }\end{array}$ & NGRIP \\
\hline 541 & 12060 & $\begin{array}{c}\text { inter-YD warm } \\
\text { event }\end{array}$ & NGRIP \\
\hline 561 & 12400 & $\begin{array}{l}\text { inter-YD cold } \\
\text { event }\end{array}$ & MD95-2042 \\
\hline 611 & 12860 & Gl1a & MD95-2042 \\
\hline 631 & 13080 & Gl1b & MD95-2042 \\
\hline 701 & 13422 & Gl1c1 & MD95-2042 \\
\hline 721 & 13520 & Gl1c2 & MD95-2042 \\
\hline 741 & 13740 & Gl1c3 & MD95-2042 \\
\hline 801 & 14040 & Gl1d & MD95-2042 \\
\hline 841 & 14360 & warm Gl1e & MD95-2042 \\
\hline 861 & 14420 & cold Gl1e & MD95-2042 \\
\hline 921 & 14500 & warm Gl1e & MD95-2042 \\
\hline 981 & 15260 & $\begin{array}{l}\text { inter-H1b cold } \\
\text { event }\end{array}$ & MD95-2042 \\
\hline 1001 & 15420 & $\begin{array}{c}\text { inter-H1b warm } \\
\text { event }\end{array}$ & MD95-2042 \\
\hline 1061 & 15640 & $\begin{array}{l}\text { inter-H1b cold } \\
\text { event }\end{array}$ & MD95-2042 \\
\hline 1081 & 15760 & $\begin{array}{c}\text { inter-H1b warm } \\
\text { event }\end{array}$ & MD95-2042 \\
\hline 1141 & 16060 & $\begin{array}{c}\text { inter-H1b warm } \\
\text { event }\end{array}$ & MD95-2042 \\
\hline 1221 & 16400 & $\begin{array}{l}\text { inter-H1ss cold } \\
\text { event }\end{array}$ & MD95-2042 \\
\hline 1261 & 16620 & $\begin{array}{l}\text { inter-H1ss } \\
\text { warm event }\end{array}$ & MD95-2042 \\
\hline
\end{tabular}




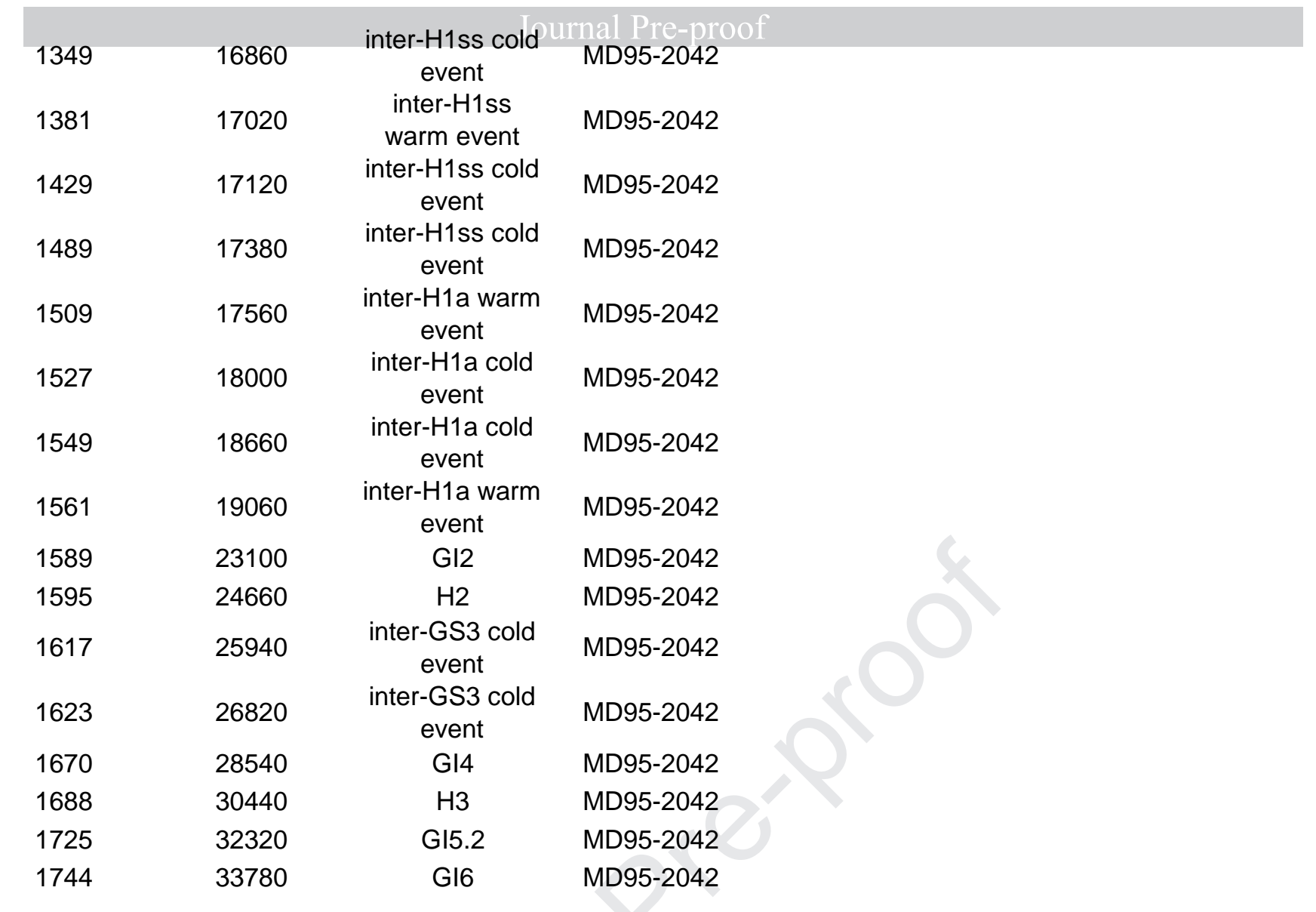


Adelosina longirostra (d'Orbigny, 1846)

Adelosina pulchella (d'Orbigny, 1826)

Alveolophragmium orbiculatum Shchedrina, 1936

Ammonia beccarii (Linnaeus, 1758)

Amphicoryna bradii (Silvestri, 1902)

Amphicoryna hirsuta (d'Orbigny, 1826)

Amphicoryna intercellularis (Brady, 1881)

Amphicoryna scalaris (Batsch, 1791)

Amphicoryna separans (Brady, 1884)

Astacolus crepidulus (Fichtel \& Moll, 1798)

Asterigerinata mamilla (Williamson, 1858)

Bigenerina (Bigenerina) nodosaria d'Orbigny, 1826

Bolivina alata (Seguenza, 1862)

Bolivina earlandi Parr, 1950

Bolivina italica Cushman, 1936

Bolivina pseudoplicata Heron-Allen \& Earland, 1930

Bolivina pygmaea (Brady, 1881)

Bolivina spathulata (Williamson, 1858)

Bolivina subaenariensis Cushman, 1922

Bolivinita quadrilatera (Schwager, 1866)

Buccella frigida (Cushman, 1922)

Bulimina aculeata d'Orbigny, 1826

Bulimina gibba Fornasini, 1902

Bulimina marginata d'Orbigny, 1826

Bulimina truncana Gumbel, 1868

Bulimina striata d'Orbigny, in Guérin-Méneville, 1832

Cancris auricula (Fichtel \& Moll, 1798)

Cassidulina laevigata d'Orbigny, 1826

Chilostomella oolina Schwager, 1878

Chilostomella ovoidea Reuss, 1850

Cibicides refulgens de Montfort, 1808

Cibicidoides lobatulus (Walker \& Jacob, 1798)

Cibicidoides pachyderma (Rzehak, 1886)

Cibicidoides pseudoungeriana (Cushman, 1922)

Cibicidoides wuellerstorfi (Schwager, 1866)

Cornuspira carinata (Costa, 1856)

Cornuspira foliacea (Philippi, 1844)

Cribroelphidium excavatum (Terquem, 1875)

Cribroelphidium gerthi Van Voorthuysen, 1957

Cyclammina cancellata Brady, 1879

Discorbinella bertheloti (d'Orbigny, 1839)

Dorothia pseudoturris (Cushman, 1922)

Edentostomina cultrata (Brady, 1881)

Eggerella bradyi (Cushman, 1911)

Elphidium articulatum (d'Orbigny, 1839)

Elphidium crispum (Linnaeus, 1758)

Entzia macrescens (Brady, 1870)

Eponides repandus (Fichtel \& Moll, 1798)

Eubuliminella exilis (Brady, 1884)

Evolvocassidulina bradyi (Norman, 1881)

Favulina hexagona (Williamson, 1848)

Favulina squamosa (Montagu, 1803)

Fissurina cucullata Silvestri, 1902

Fissurina marginata (Montagu, 1803)

Fissurina (Fissurina) orbignyana Seguenza, 1862

Fissurina lucida (Williamson, 1848)

Fursenkoina bradyi (Cushman, 1922)

Fursenkoina complanata (Egger, 1893)

Gavelinopsis praegeri (Heron-Allen \& Earland, 1913)
Gavelinopsis translucens (Phleger \& Parker, 1951)

Glandulina ovula d'Orbigny, 1846

Globobulimina affinis (d'Orbigny, 1839)

Globobulimina auriculata (Bailey, 1894)

Globobulimina pyrula (d'Orbigny, 1846)

Globobulimina sp. ccff. ovula (d'Orbigny, 1839)

Globocassidulina crassa (d'Orbigny, 1839)

Globocassidulina subglobosa (Brady, 1881)

Globulina gibba (d'Orbigny in Deshayes, 1832)

Grigelis guttiferus (d'Orbigny, 1846)

Grigelis orectus Loeblich \& Tappan, 1994

Gyroidina umbonata (Silvestri, 1898)

Hansenisca soldanii (d'Orbigny, 1826)

Haynesina depressula (Walker \& Jacob, 1798)

Hoeglundina elegans (d'Orbigny, 1826)

Homalohedra acuticosta (Reuss, 1862)

Hyalinea balthica (Schröter in Gmelin, 1791)

Hyalinonetrion gracillima (Seguenza, 1862)

Karreriella bradyi (Cushman, 1911)

Karreriella novangliae (Cushman, 1922)

Laevidentalina advena (Cushman, 1923)

Laevidentalina elegans (d'Orbigny, 1846)

Laevidentalina filiformis (d'Orbigny, 1826)

Laevidentalina inornata (d'Orbigny, 1846)

Laevidentalina subsoluta (Cushman, 1923)

Lagena elongata Dunikowski, 1879

Lagena hispidula Cushman, 1913

Lagena semistriata Williamson, 1848

Lagena striata (d'Orbigny, 1839)

Lagena substriata Williamson, 1848

Lagena sulcata (Walker \& Jacob, 1798)

Lenticulina calcar (Linnaeus, 1758)

Lenticulina gibba (d'Orbigny, 1826)

Lenticulina iota (Cushman, 1923)

Lenticulina orbicularis (d'Orbigny, 1826)

Lingulina carinata d'Orbigny, 1826

Lingulina seminuda Hantken, 1875

Marginulina obesa Cushman, 1923

Marginulina similis d'Orbigny, 1846

Marginulinopsis bradyi (Goës, 1894)

Marginulinopsis tenuis (Bornemann, 1855)

Melonis affinis (Reuss, 1851)

Melonis pompilioides (Fichtel \& Moll, 1798)

Miliolinella elongata Kruit, 1955

Miliolinella circularis (Bornemann, 1855)

Miliolinella subrotunda (Montagu, 1803)

Neoconorbina terquemi (Rzehak, 1888)

Neolenticulina variabilis (Reuss, 1850)

Nodosaria simplex Silvestri, 1872

Nonion boueanum (d'Orbigny, 1846)

Nonion commune (d'Orbigny, 1846)

Nonionella sp. ccff. bradii (Chapman, 1917)

Nonionellina labradorica (Dawson, 1860)

Nonionoides turgidus (Williamson, 1858)

Oolina globosa (Montagu, 1803)

Orthomorphina perversa (Schwager, 1866)

Parafissurina malcolmsonii (Wright, 1911)

Patellina corrugata Williamson, 1858

Pileolina patelliformis (Brady, 1884)
Planorbulina mediterranensis d'Orbigny, 1826

Planulina ornata (d'Orbigny, 1839)

Pleurostomella sp.

Porosononion granosum (d'Orbigny, 1846)

Pseudonodosinella nodulosa (Brady, 1879)

Pseudononion japonicum Asano, 1936

Pullenia bulloides (d'Orbigny, 1846)

Pullenia quinqueloba (Reuss, 1851)

Pyrgo bulloides (d'Orbigny, 1826)

Pyrgo elongata (d'Orbigny, 1826)

Pyrgo denticulata (Brady, 1884)

Pyrgo laevis Defrance, 1824

Pyrgo lucernula (Schwager, 1866)

Pyrgo murrhina (Schwager, 1866)

Pyrgo ringens (Lamarck, 1804)

Pyrgo williamsoni (Silvestri, 1923)

Pyrgoella irregularis (d'Orbigny, 1839)

Pyrgoella sphaera (d'Orbigny, 1839)

Pyrulina angusta (Egger, 1857)

Pyrulina cylindroides (Roemer, 1838)

Quinqueloculina lamarckiana d'Orbigny, 1839

Quinqueloculina lata Terquem, 1876

Quinqueloculina seminula (Linnaeus, 1758)

Reophax curtus Cushman, 1920

Reophax scorpiurus Montfort, 1808

Reussoolina laevis (Montagu, 1803)

Rosalina globularis d'Orbigny, 1826

Rosalina irregularis (Rhumbler, 1906)

Rosalina williamsoni (Chapman \& Parr, 1932)

Sahulia conica (d'Orbigny, 1839)

Seguenzaella lacunata (Burrows \& Holland, 1895)

Sigmoilopsis schlumbergeri (Silvestri, 1904)

Sigmomorphina sp.

Sigmopyrgo vespertilio (Sclumberger, 1891)

Siphogenerina columellaris (Brady, 1881)

Siphotextularia concava (Karrer, 1868)

Siphouvigerina proboscidea (Schwager, 1866)

Sphaeroidina bulloides d'Orbigny in Deshayes, 1828

Spirillina vivipara Ehrenberg, 1843

Spiroloculina excavata d'Orbigny, 1846

Spiroloculina henbesti Petri, 1955

Spiroloculina nitida d'Orbigny, 1826

Stainforthia fusiformis (Williamson, 1848)

Textularia agglutinans d'Orbigny, 1839

Textularia pseudogramen Chapman \& Parr, 1937

Textularia sagittula Defrance, 1824

Trifarina angulosa (Williamson, 1858)

Trifarina bradyi Cushman, 1923

Triloculina oblonga (Montagu, 1803)

Triloculina tricarinata d'Orbigny in Deshayes, 1826

Triloculina trigonula (Lamarck, 1804)

Trochammina inflata (Montagu, 1808)

Uvigerina asperula Czjzek, 1848

Uvigerina auberiana d'Orbigny, 1839

Uvigerina canariensis d'Orbigny, 1839

Uvigerina cushmani Todd, 1948

Uvigerina peregrina Cushman, 1923

Valvulineria bradyana (Fornasini, 1900) 


\begin{tabular}{|c|c|c|}
\hline Species & Microhabitat & 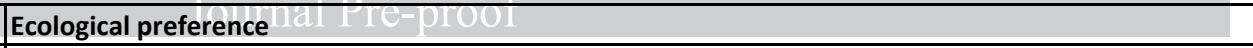 \\
\hline $\begin{array}{l}\text { Cassidulina } \\
\text { laevigata } \\
\text { d'Orbigny, } 1826\end{array}$ & $\begin{array}{l}\text { Shallow infaunal } \\
\text { (Fontanier et al., } \\
2002 \text { ) }\end{array}$ & $\begin{array}{l}\text { Cassidulina laevigata is an opportunistic species adapted to high food concentration (Baas et al., } \\
\text { 1998), related to high flux of organic carbon (>3 gC/m/yr) (Jorissen et al., 2007). It is common in } \\
\text { areas with seasonal intermittent organic matter (OM) fluxes (Rasmussen et al., 2002). Suboxic } \\
\text { species (Kaiho, 1994), though it can be present in shallow, well oxygented microhabitats with } \\
\text { elevated flux of OM (Stigter et al., 1998). It is related with upwelling currents (Levy et al., 1995). } \\
\text { In Portugal it occurs during glacial periods, with maxima coincident with palaeoproductivity } \\
\text { (Baas et al., 1998). C. laevigata is also common during MIS } 4 \text { and LGM in deep sites from the } \\
\text { Bay of Biscay, SW of Landas shelf (Rodriguez-Lazaro et al., 2017). }\end{array}$ \\
\hline $\begin{array}{l}\text { Uvigerina } \\
\text { peregrina } \\
\text { Cushman, } 1923\end{array}$ & $\begin{array}{l}\text { Shallow/intermediat } \\
\text { e infaunal } \\
\text { (Fontanier et al., } \\
\text { 2002; Singh et al., } \\
2015 \text { ) }\end{array}$ & $\begin{array}{l}\text { Uvigerina peregrina is a cold-cool water species }\left(2^{\circ}-15^{\circ} \mathrm{C}\right) \text { (Murray, 1991). It occurs in sediments } \\
\text { rich in OM (Seiglie, 1968; Fontanier et al., 2002; Singh et al., 2015) with high flux of organic } \\
\text { carbon }\left(2-3 \mathrm{~g} / \mathrm{m}^{2} \text { a) (Altenbach, 1988). Typical of mesotrophic and oligotrophic environments }\right. \\
\text { (Mojtahid et al., 2010), indicating high productivity (Lutze, 1986; Rai and Singh, 2012; Patarroyo } \\
\text { and Martinez, 2016). } \\
\text { This species suggests strong seasonality with OM and/or phytodetritus exported from the surface } \\
\text { (García et al., 2013). It is suboxic (Kahio, 1994) and adapted to low-moderate oxygen content } \\
\text { (Lutze, 1986; Singh et al., 2015). It can be the main species in upwelling areas (Debenay and } \\
\text { Konate, 1987). Its occurrence seems to be influenced by the upper North Atlantic Deep Water } \\
\text { (NADW) or the Circumpolar Deep Water (CDW) (Schnitker, 1979). It is also common during } \\
\text { MIS } 1 \text { from deep areas of the Bay of Biscay (Rodriguez-Lazaro et al., 2017). }\end{array}$ \\
\hline $\begin{array}{l}\text { Hyalinea balthica } \\
\text { (Schröter, 1783) }\end{array}$ & $\begin{array}{l}\text { Shallow/intermediat } \\
\text { e infaunal (Singh et } \\
\text { al., 2015; Fontanier } \\
\text { et al., 2002) }\end{array}$ & $\begin{array}{l}\text { Hyalinea balthica is very abundant in N Atlantic cold water masses (Murray, 1973). Dominant } \\
\text { species during glacials (Martins and Ruivo Dragao Gomes, 2004), with high percentages during } \\
\text { MIS 3, 2, and lower during the Holocene (Ross, 1984). It is considered an opportunistic species } \\
\text { that benefits of food availability (Hess and Jorissen, 2009; Rosenthal et al., 2011). Characteristic } \\
\text { of low-oxygen sediments with elevated oceanic productivity (Martins and Ruivo Dragao Gomes, } \\
\text { 2004), it can be found living in deep sediments with total anoxia (Rosenthal et al., 2011). It is } \\
\text { dominant species in the Cap Breton Canyon (N Atlantic), into high OM, mesotrophic to eutrophic, } \\
\text { low-oxygen sediments (Hess and Jorissen, 2009), evidencing an early phase of ecosystem } \\
\text { recolonisation after turbiditic deposition. }\end{array}$ \\
\hline $\begin{array}{l}\text { Bolivina } \\
\text { subaenariensis } \\
\text { Cushman, } 1922\end{array}$ & $\begin{array}{l}\text { Shallow infaunal } \\
\text { (Fontanier et al., } \\
\text { 2002) }\end{array}$ & $\begin{array}{l}\text { Bolivina subaenariensis is a cold water species (Murray, 2006), characteristic of hypoxic } \\
\text { environments it can live in low oxygen sediments with } \mathrm{H}_{2} \mathrm{~S} \text { (Pujos-Lamy, 1973). Then it is a proxy } \\
\text { species of dysoxic sediments (Kaiho, 1994). It is more abundant when terrigenous decrease and } \\
\text { biogenic components increase in sediment (Levy et al., 1995), being dominant in silty, high OM } \\
\text { sediments related to upwellings (Sen Gupta et al., 1981). Species associated, together with } H \text {. } \\
\text { balthica with high OM, low oxygen sediments in meso-eutrophic environments. It is dominant } \\
\text { species in the Cap Breton Canyon (N Atlantic) (Hess and Jorissen, 2009) and Saint-Tropez } \\
\text { Canyon in the Mediterranean (Fontanier et al., 2008), both species evidencing an early phase of } \\
\text { ecosystem recolonisation after turbiditic deposition. }\end{array}$ \\
\hline $\begin{array}{l}\text { Cibicidoides } \\
\text { pachyderma } \\
\text { (Rzehak, 1886) }\end{array}$ & $\begin{array}{l}\text { Shallow infaunal } \\
\text { (Fontanier et al., } \\
\text { 2002) }\end{array}$ & $\begin{array}{l}\text { Cibicidoides pachyderma is present in waters with T higher than } 5^{\circ} \mathrm{C} \text { (Healey et al., 2008) and } \\
\text { high oxygen content (Schmiedl et al., 2000; Kuhnt et al., 2007). This species lives in oligo- } \\
\text { mesotrophic areas (Schmiedl et al., 2000). It is indicator of low to moderate OM availability } \\
\text { (Kuhnt et al., 2007) and high energy environments (Kitazato, 1994). }\end{array}$ \\
\hline $\begin{array}{l}\text { Bolivina } \\
\text { spathulata } \\
\text { (Williamson, 1858) }\end{array}$ & $\begin{array}{l}\text { Shallow infaunal } \\
\text { (Singh et al., 2015) }\end{array}$ & $\begin{array}{l}\text { Bolivina spathulata inhabits waters with T range of } 17-25^{\circ} \mathrm{C} \text { (Murray, 2006). It is abundant in } \\
\text { poor oxygen, rich OM with elevated productivity environments (Alavi, 1988). It is a species } \\
\text { indicator of dysoxia (Kaiho, 1994) }\left(\mathrm{O}_{2}: 0.1-0.3 \mathrm{ml} / \mathrm{l}\right) \text {. Their populations increase rapidly with } \\
\text { phytoplankton bloom produced by upwelling (Diz et al., 2006). It stands a wide variety of } \\
\text { hydrographic bottom contitions (Singh et al, 2015). }\end{array}$ \\
\hline $\begin{array}{l}\text { Globobulimina } \\
\text { affinis (d'Orbigny, } \\
1839 \text { ) }\end{array}$ & $\begin{array}{l}\text { Deep infaunal } \\
\text { (Fontanier et al, } \\
\text { 2002; Geslin et al., } \\
2004 \text { ) }\end{array}$ & $\begin{array}{l}\text { Globobulimina is a cold water genus. Gl. affinis is bathyal and lives in high OM sediments } \\
\text { (Fontanier et al., 2005), in high productivity and low oxygen areas (Hayek and Wilson, 2013; } \\
\text { Patarroyo and Martinez, 2016). In the classification of Kaiho, } 1994 \text { it is considered as dyxosic } \\
\text { species that can stand anoxic conditions (Geslin et al., 2004; Fontanier et al., 2002). Thus it is a } \\
\text { useful proxy to detect levels of extremely low oxygen rates (Schonfeld, 2001; Jorissen et al., } \\
\text { 2007; Grunert et al., 2015). It occurs during H4 in Portugal (Baas et al., 1998), as well as in H1 } \\
\text { and H4 with maxima IRD in Bay of Biscay (Loncaric et al., 1998). Also abundant in deep sites } \\
(2882 \text { m) SW of Landas shelf (Bay of Biscay) during MIS } 4 \text { to MIS } 2 \text { and H6 (Rodriguez-Lazaro } \\
\text { et al., 2017). }\end{array}$ \\
\hline
\end{tabular}




\begin{tabular}{|c|c|c|}
\hline Nonionoides & Deep infaunal & Nonionoides turgidus is an opportunistic species associated with nutrients increasing (Jorissen, \\
\hline $\begin{array}{l}\text { turgidus } \\
\text { (Williamson, 1858) }\end{array}$ & $\begin{array}{l}\text { (Corliss and } \\
\text { Emerson, 1990; } \\
\text { Corliss, 1991) }\end{array}$ & $\begin{array}{l}\text { 1987; van der Zwaan and Jorissen, 1991; Alve and Bernhard, 1995). It occurs in low } \\
\text { hydrodynamic, high low-quality OM, hypoxic sediments (Goineau et al., 2011). It is cited as } \\
\text { seasonal species during eutrophization and stratification phases (Jorissen et al., 1992). Living in } \\
\text { low oxygen habitats (van der Zwaan and Jorissen, 1991; Bernhard and Sen Gupta, 1999) and it } \\
\text { stands permanent oxygen depletion (Moodley et al., 1998). It is considered as suboxic by Kaiho, }\end{array}$ \\
\hline $\begin{array}{l}\text { Chilostomella } \\
\text { oolina Schwager, } \\
1878\end{array}$ & $\begin{array}{l}\text { Deep infaunal } \\
\text { (Mackensen and } \\
\text { Douglas, 1989, } \\
\text { Mojtahid et al., } \\
\text { 2010). Intermediate } \\
\text { infaunal (Fontanier } \\
\text { et al., 2002). }\end{array}$ & $\begin{array}{l}\text { Chilostomella oolina is very abundant in S Bay of Biscay, where the OM is included in sediments } \\
\text { strongly hypoxic or anoxic (Fontanier et al., 2002). Species indicative of dysoxia }\left(\mathrm{O}_{2}: 0.1-0.3 \mathrm{ml} / \mathrm{l}\right) \\
\text { (Kahio, 1994), though it can adapt to suboxic conditions (Rathburn and Corliss, 1994). In stressed } \\
\text { environments this species has competitive advantage over other living near the surface (Rathburn } \\
\text { and Corliss, 1994). In case of low quality degraded OM, this species is replaced by Gl. affinis } \\
\text { (Fontainer et al., 2002). Both species prefer living in areas with high OM and low carbonate } \\
\text { content (De Rijk et al.,1999). }\end{array}$ \\
\hline $\begin{array}{l}\text { Bulimina gibba } \\
\text { Fornasini, } 1902\end{array}$ & $\begin{array}{l}\text { Deep infaunal } \\
\text { (Fontanier et al., } \\
\text { 2002; Mendes et al., } \\
\text { 2004) }\end{array}$ & $\begin{array}{l}\text { Bulimina gibba is living in cold to temperate waters }\left(5^{\circ}-17^{\circ} \mathrm{C}\right) \text { (Murray, 1991) with high } \\
\text { productivity (Rai and Singh, 2012), thus it is extremely eutrophic and anoxic (Fontanier et al., } \\
\text { 2002). It is a dysoxic species }\left(\mathrm{O}_{2}: 0.1-0.3 \mathrm{ml} / \mathrm{l}\right) \text { after Kahio, 1994. Abundant during interestadials } \\
\text { MIS 5a, c, e, in deep sites }(2882 \mathrm{~m}) \text { of Bay of Biscay (Rodriguez-Lazaro et al., 2017). }\end{array}$ \\
\hline $\begin{array}{l}\text { Melonis affinis } \\
\text { (Reuss, 1851) }\end{array}$ & $\begin{array}{l}\text { Shallow/intermediat } \\
\text { e infaunal } \\
\text { (Fontanier et al., } \\
\text { 2002; Grunert et al, } \\
\text { 2015; Singh et al., } \\
2015 \text { ) }\end{array}$ & $\begin{array}{l}\text { Melonis affinis, (previously: Melonis barleeanus) is a cold water species }\left(-0.4^{\circ} \text { to } 9^{\circ} \mathrm{C} \text { ) (Murray, }\right. \\
\text { 1991) and tolerates high degraded OM content (Fontanier et al., 2002). It is considered as suboxic } \\
\text { (Kaiho, 1994), it can occur in oxygen depleted, low nitrates content sediments (Jorissen et al., } \\
\text { 1998). It indicates mesotrophic conditions (Grunert et al., 2015; Jorissen, 2003). It is present in } \\
\text { deep waters of Landas shelf in Bay of Biscay, during stadial MIS 5d (Rodriguez-Lazaro et al., } \\
\text { 2017) }\end{array}$ \\
\hline $\begin{array}{l}\text { Bigenerina } \\
\text { (Bigenerina) } \\
\text { nodosaria } \\
\text { d'Orbigny, } 1826\end{array}$ & $\begin{array}{l}\text { Epifaunal (Murray, } \\
\text { 2006)/Shallow } \\
\text { infaunal (Fontanier } \\
\text { et al., 2002) }\end{array}$ & $\begin{array}{l}\text { Bigenerina nodosaria inhabits waters with T below } 15^{\circ} \mathrm{C} \text { (Mathieu, 1986). It dominates during } \\
\text { interglacial periods, as MIS } 1 \text { and indicates increasing of surface productivity associated to warm } \\
\text { episodes (Angue Minto'o et al., 2016). It is opportunistic in outer shelf of Bay of Biscay after } \\
\text { phytoplankton blooms (Duchemin et al., 2008). It has also been associated with marine } \\
\text { phytodetritus (Fontanier et al., 2008). }\end{array}$ \\
\hline
\end{tabular}




\section{Conflicts of Interest Statement}

The authors whose names are listed immediately below certify that they have NO affiliations with or involvement in any organization or entity with any financial interest (such as honoraria; educational grants; participation in speakers' bureaus; membership, employment, consultancies, stock ownership, or other equity interest; and expert testimony or patent-licensing arrangements), or non-financial interest (such as personal or professional relationships, affiliations, knowledge or beliefs) in the subject matter or materials discussed in this manuscript.

Author names: Ana Pascual, Julio Rodriguez-Lazaro, Blanca Martínez-García and Zeltia Varela

Manuscript title: Climate changes during the last 37,000 years detected in the SE Bay of Biscay based on benthic foraminifera 